Priročnik za naročnike in ponudnike storitev zasebnega varovanja v Republiki Sloveniji

Urednik: Miha Dvojmoč

Projekt Zagotavljanje in naročanje zasebne varnosti v Republiki Sloveniji sofinancirata Republika Slovenija in Evropska unija iz Evropskega socialnega sklada. 


\section{ZAGOTAVLJANJE IN NAROČANJE ZASEBNE VARNOSTI V REPUBLIKI SLOVENIJI}

Priročnik za naročnike in ponudnike storitev zasebnega varovanja v Republiki Sloveniji

Urednik: Miha Dvojmoč

november 2019 


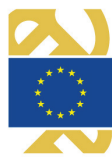

EVROPSKA UNIJA

EVROPSKI

SOCIALNI SKLAD

Projekt Zagotavljanje in naročanje zasebne varnosti v Republiki Sloveniji sofinancirata Republika Slovenija in Evropska unija iz evropskega socialnega sklada

Naslov Title

Podnaslov Subtitle

Urednik Edito

Avtorji Authors

Tehnična urednika Technical editors

Lektoriranje Language editing Oblikovanje ovitka Cover designer Grafike na ovitku Cover graphics Grafične priloge Graphics material

Založnik Published by

Izdajatelj Co-published by

Izdaja Edition

Vrsta publikacije Publication type

Izid Published

Dostopno na Availabe at

ISBN

DOI

Cena Price

Odgovorna oseba založnika For publisher
Zagotavljanje in naročanje zasebne varnosti v Republiki Sloveniji

Providing and Ordering Private Security in the Republic of Slovenia

Priročnik za naročnike in ponudnike storitev zasebnega varovanja v Republiki Sloveniji

A Guide for Subscribers and Providers of Private Security Services in the Republic of Slovenia

Miha Dvojmoč

(Univerza v Mariboru, Fakulteta za varnostne vede)

Miha Dvojmoč

Boštjan Ban

(Univerza v Mariboru, Fakulteta za varnostne vede)

Miloš Beković

(Univerza v Mariboru, Fakulteta za varnostne vede)

Univerza v Mariboru, Fakulteta za elektrotehniko, računalništvo in informatiko)

Gorazd Mandel

(GM PROJEKT, projektni management, elektrotehnični inženiring in poslovno svetovanje, d. o. o.)

Andrej Sotlar

(Univerza v Mariboru, Fakulteta za varnostne vede)

Milan Vačovnik

(AKTIVA PRIVA družba za storitve, trgovino

in proizvodnjo, d. o. o.)

Anja Babnik

(Univerza v Mariboru, Fakulteta za varnostne vede)

Tina Dernovšek

Eva Blatnik

(Univerza v Mariboru, Fakulteta za varnostne vede)

Tina Dernovšek

(Univerza v Ljubljani, Akademija za likovno umetnost in oblikovanje)

Nika Gaberšek

(Univerza v Mariboru, Fakulteta za varnostne vede)

Daniela Hozjan

(Univerza v Mariboru, Fakulteta za varnostne vede)

Mitja Prešljić

(Univerza v Mariboru, Fakulteta za varnostne vede)

Jan Perša

(Univerzitetna založba Univerze v Mariboru)

(Univerza v Ljubljani, Akademija za likovno umetnost in oblikovanje)

Andreja Breznik

Tina Dernovšek

Tina Dernovšek

Tina Dernovšek

Univerzitetna založba Univerze v Mariboru

Slomškov trg 15, 2000 Maribor, Slovenija

http://press.um.si, zalozba@um.si

Univerza v Mariboru, Fakulteta za varnostne vede

Kotnikova ulica 8, 1000 Ljubljana, Slovenija

https://fvv.um.si, fvv@fvv.uni-mb.si

Prva izdaja

E-knjiga

Maribor, november 2019

http://press.um.si/index.php/ump/catalog/book/445

978-961-286-316-6 (pdf)

https://doi.org/10.18690/978-961-286-316-6

Brezplačni izvod

prof. dr. Zdravko Kačič, rektor Univerze v Mariboru

CIP - Kataložni zapis o publikaciji

Univerzitetna knjižnica Maribor

$351.746 .2 / .3: 351.712(082)(0.034 .2)$

ZAGOTAVLJANJE in naročanje zasebne varnost

v Republiki Sloveniji [Elektronski vir] : priročnik

za naročnike in ponudnike storitev zasebnega varovanja

v Republiki Sloveniji / urednik Miha Dvojmoč ; [avtor

ji Miha Dvojmoč ... et al.]. - 1. izd. - El. knjiga.

Maribor : Univerzitetna založba Univerze, 2019

Način dostopa (URL): http://press.um.si/index.php/ump/

catalog/book/44

ISBN 978-961-286-316-6 (pdf)

doi: $10.18690 / 978-961-286-316-6$

1. Dvojmoč, Miha

COBISS.SI-ID 9756723

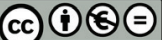

(c) Univerza v Mariboru, Univerzitetna založba

University of Maribor, University Press

Besedilo Text (C) avtorji, 2019

Ta publikacija je izdana pod licenco Creative Commons Priznanje avtorstva-Nekomercialno-Brez predelav 4.0 Mednarodna.

This work is licensed under the Creative Commons Attribution-NonCommer cial-NoDerivs 4.0 International License.

https://creativecommons.org/licenses/by-nc-nd/4.0/ 


\section{Zagotavljanje in naročanje zasebne varnosti v Republiki Sloveniji}

\section{MIHA DVOJMOČ}

Univerza v Mariboru, Fakulteta za varnostne vede, Ljubljana, Slovenija,

e-pošta: miha.dvojmoc@fvv.uni-mb.si

Povzetek Smernice v obliki priročnika vključujejo znanja s širšega področja zagotavljanja varnosti, kot so zasebno varovanje, korporativna varnost in pravo javnega naročanja. Publikacija naročnike usmerja $\mathrm{k}$ lažjemu in pravilnejšemu izboru ponudnika zasebnovarnostnih storitev, temelji pa na analizi urejenosti področja zasebnega varovanja v kar 32 evropskih državah, na analizi značilnosti delovanja zasebnega varovanja v Sloveniji in na analizi javnega naročanja v Sloveniji. Med drugim priročnik še posebej opozarja na pomen kakovosti zasebnovarnostnih storitev, meril za izbiro ponudnika in primernega razmerja med kakovostjo ter ceno ponujenih storitev na trgu. Vključena so možna merila za naročanje oziroma izbor storitev zasebnega varovanja za različne sektorje (trgovino, javno upravo, industrijo, finančni sektor in fizične osebe - varovanje hiše), ki so pripravljeni specifično za slovenske razmere in so presek teoretičnega razmišljanja ter predlogov in izkušenj strokovnjakov iz gospodarske dejavnosti, na katero se nanašajo.

Ključne besede: zasebna varnost, javno naročanje, naročniki, ponudniki, merila naročanja.

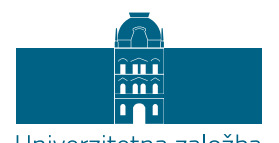

Univerzitetna založba Univerze v Mariboru
DOI https://doi.org/10.18690/978-961-286-316-6

ISBN 978-961-286-316-6 (pdf)

Dostopno na http://press.um.si/index.php/ump/catalog/book/445 


\section{VSEBINA}

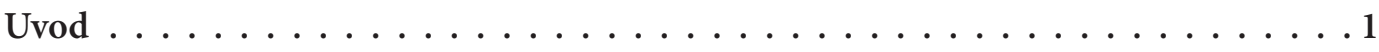

Ureditev javnega naročanja storitev zasebnega varovanja v 32 evropskih državah . . . . 3

Kratek pregled urejenosti področja zasebnega varovanja v 32 evropskih državah . . 7

Zasebno varovanje v Sloveniji . . . . . . . . . . . . . . . . . . 21

Javno naročanje v Sloveniji $\ldots \ldots \ldots$. . . . . . . . . . . . . 27

Analiza prakse javnega naročanja na področju zasebnega varovanja $\ldots . . \ldots .32$

Pregled kriterijev za izbor izvajalca storitev zasebnega varovanja . . . . . . . . 35

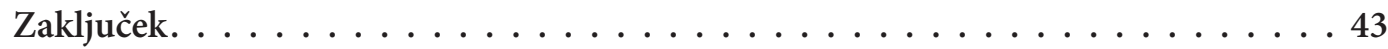

Viri in literatura. . . . . . . . . . . . . . . . . 45 
V okviru projekta »Po kreativni poti do znanja« so študentje Fakultete za varnostne vede Univerze v Mariboru in študentka Akademije za likovno umetnost Univerze v Ljubljani ob podpori delovnih in pedagoških mentorjev pripravili publikacijo, ki jo predstavljamo v nadaljevanju. Gre za priročnik za naročnike in ponudnike storitev zasebnega varovanja, ki odraža delo, razmišljanje ter ugotovitve študentov skozi proces priprave modela naročanja storitev zasebnega varovanja, ki je nastal ob pregledu literature v kombinaciji s praktičnimi napotki in nasveti delovnih mentorjev ter ob vodenju in usmerjanju pedagoških mentorjev.

Zakon o javnem naročanju v Sloveniji je precej splošen, javno naročanje na področju obrambe in varnosti pa tudi ne zajema področja zasebnega varovanja, kot smo nekoč poznali naročanje zasebnega varovanja kot možno izjemo od določenih pravil javnega naročanja s prilogo B Zakona o javnem naročanju. Ob spremljanju naročanja storitev zasebnega varovanja se nam postavlja vprašanje, ali naročniki vedo, kaj naročajo in plačujejo ter ali so za to usposobljeni. Mnogi naročniki potrebujejo konkretne usmeritve pri izbiri pravega ponudnika storitev zasebnega varovanja. $\mathrm{V}$ ta namen smo v okviru projekta pripravili smernice v obliki priročnika, v katerega so vključena znanja s širšega področja zagotavljanja varnosti, 
konkretneje pa predvsem s področij, kot so zasebno varovanje, korporativna varnost in pravo javnega naročanja. Publikacija, ki naročnike usmerja $\mathrm{k}$ lažjemu in pravilnejšemu izboru ponudnika zasebnovarnostnih storitev, temelji na analizi urejenosti področja zasebnega varovanja v kar 32 evropskih državah, na analizi značilnosti delovanja zasebnega varovanja $v$ Sloveniji in na analizi javnega naročanja v Sloveniji. Preko analize prakse javnega naročanja na področju zasebnega varovanja in izsledkov v obliki pregleda kriterijev za izbor izvajalca storitev zasebnega varovanja je tako nastal Priročnik za naročanje in zagotavljanje storitev zasebnega varovanja v Republiki Sloveniji. Med drugim priročnik še posebej opozarja na pomen kakovosti zasebnovarnostnih storitev, meril za izbiro ponudnika in primernega razmerja med kakovostjo ter ceno ponujenih storitev na trgu.

Priročnik vsebuje možne kriterije za naročanje oziroma izbor storitev zasebnega varovanja za različne sektorje: trgovino, javno upravo, industrijo, finančni sektor in fizične osebe (varovanje hiše). Kriteriji se od do sedaj predstavljenih razlikujejo predvsem po tem, da so pripravljeni specifično za slovenske razmere in so presek teoretičnega razmišljanja ter predlogov in izkušenj strokovnjakov iz gospodarske dejavnosti, na katero se nanašajo. 


\section{Ureditev javnega naročanja storitev zasebnega varovanja v dvaintridesetih evropskih državah}

Opravili smo primerjalno analizo ureditve zasebnega varovanja in še posebej javnega naročanja storitev zasebnega varovanja v 32 evropskih državah.

$\mathrm{V}$ analizo je bilo vključenih 28 držav Evropske unije, Bosna in Hercegovina, Črna gora, Severna Makedonija in Srbija. Tabela 1 se nanaša na samo zakonsko ureditev zasebnega varovanja, tabela 2 pa na javno naročanje storitev zasebnega varovanja. 
Panoga zasebnega varovanja s posebno zakonodajo ni regulirana v Avstriji, na Češkem in Nemčiji. V večini držav imajo varnostniki posebej določena pooblastila. Varnostno osebje v večini držav lahko ustavi osebo, uporabi fizično silo, pomaga v stiski, opravi preiskavo, zaseže predmete, zadrži osebo do prihoda policije, nosi in uporabi orožje. V državah, kot so Češka, Ciper, Irska, Litva, Luksemburg, Makedonija in Srbija, se pristojnosti varnostnikov ne razlikujejo dosti od pristojnosti državljanov.

$\mathrm{V}$ večini držav je varovanje kritične infrastrukture, kot so letališča, pristanišča in elektrarne, zaupano tudi zasebnovarnostnim podjetjem.

Ob preverjanju podatka BDP na prebivalca ni bilo zaznati posebnega vpliva višine BDP na zakonsko ureditev področja zasebnega varovanja $\mathrm{v}$ posamezni državi.

Večina držav se je najverjetneje zaradi zagotavljanja višje stopnje profesionalizacije področja zasebnega varovanja in dejanskih potreb po dejstvu, da zasebno varovanje opravljajo osebe brez varnostnih zadržkov, ki lahko pomenijo sum za izrabo upravičenj, ki jih varnostno osebje ima za potrebe, ki niso skladne z namenom pridobitve upravičenj.

Pri pregledu zakonodaje o javnem naročanju pri posameznih državah smo ugotovili, da samo v Severni Makedoniji nimajo razvitega tega področja zakonodaje. Pri vprašanju, ali imajo merila kakovosti za nakup storitev zasebnega varovanja, lahko navedemo naslednje podatke - v četrtini držav nimajo meril za nakup storitev zasebnega varovanja, pri šestih državah podatka ne najdemo, pri ostalih štirinajstih državah pa imajo merila, vendar v večini primerov kot obvezne zakonske zahteve, kot jih najdemo pri nas v Zakonu o javnem naročanju oziroma Zakonu o zasebnem varovanju. $V$ šestih državah je zaslediti tako kvalitativna kot kvantitativna merila, $v$ treh državah glede na kakovost, $\mathrm{v}$ osmih pa glede na ceno. Za ostale države nismo našli podatka. Podatki, ki smo jih pridobili ob pregledu zakonskih podlag in spletnih strani 32 izbranih držav, so še utrdili prepričanje, da je bila odločitev o pripravi modela naročanja zasebnovarnostnih storitev v okviru projekta »Po kreativni poti do znanja« pravilna. 


\begin{tabular}{|c|c|c|c|c|c|c|}
\hline \multicolumn{7}{|l|}{ ZASEBNO VAROVANJE } \\
\hline DRŽAVA & $\begin{array}{l}\text { Ali je } \\
\text { panoga } \\
\text { regulirana? }\end{array}$ & $\begin{array}{l}\text { Ali je } \\
\text { poklic } \\
\text { reguliran? }\end{array}$ & $\begin{array}{c}\text { Ali imajo } \\
\text { varnostniki } \\
\text { posebej določena } \\
\text { pooblastila? }\end{array}$ & $\begin{array}{l}\text { Ali je država prenesla } \\
\text { na varnostna podjetja } \\
\text { varovanje kritične } \\
\text { infrastrukture? }\end{array}$ & $\begin{array}{l}\text { Ali je varnostno } \\
\text { osebje v obravna- } \\
\text { vani državi varno- } \\
\text { stno preverjeno? }\end{array}$ & $\begin{array}{l}\text { BDP na } \\
\text { prebivalca } \\
\text { za leto 2017 } \\
\text { [USD] }\end{array}$ \\
\hline AVSTRIJA & $\mathrm{NE}$ & $\mathrm{DA}$ & $\mathrm{DA}$ & l & $\mathrm{DA}$ & $47.290,91$ \\
\hline BELGIJA & $\mathrm{DA}$ & DA & $\mathrm{DA}$ & DA & $\mathrm{DA}$ & $43 \cdot 323,81$ \\
\hline BOLGARIJA & DA & $\mathrm{DA}$ & $\mathrm{DA}$ & DA & DA & $8.031,60$ \\
\hline BOSNA IN HERCEGOVINA & DA & $\mathrm{DA}$ & $\mathrm{DA}$ & DA & $\mathrm{DA}$ & $5.180,64$ \\
\hline CIPER & $\mathrm{DA}$ & DA & DA & $\mathrm{NE}$ & $\mathrm{DA}$ & $25.233,57$ \\
\hline ČEŠKA & $\mathrm{NE}$ & $\mathrm{NE}$ & $\mathrm{NE}$ & $\mathrm{NE}$ & $\mathrm{DA}$ & $20.368,14$ \\
\hline ČRNA GORA & $\mathrm{DA}$ & $\mathrm{DA}$ & $\mathrm{DA}$ & $\mathrm{DA}$ & $\mathrm{DA}$ & $7.669,57$ \\
\hline DANSKA & DA & I & $\mathrm{NE}$ & $\mathrm{DA}$ & I & $56.307,51$ \\
\hline ESTONIJA & DA & $\mathrm{DA}$ & $\mathrm{DA}$ & DA & DA & $19.704,66$ \\
\hline FINSKA & DA & $\mathrm{DA}$ & $\mathrm{DA}$ & DA & $\mathrm{DA}$ & $45.703,33$ \\
\hline FRANCIJA & $\mathrm{DA}$ & $\mathrm{DA}$ & $\mathrm{DA}$ & DA & $\mathrm{DA}$ & $38.476,66$ \\
\hline GRČIJA & $\mathrm{DA}$ & $\mathrm{DA}$ & $\mathrm{NE}$ & $\mathrm{DA}$ & $\mathrm{DA}$ & $18.613,42$ \\
\hline HRVAŠKA & $\mathrm{DA}$ & $\mathrm{DA}$ & $\mathrm{DA}$ & DA & $\mathrm{DA}$ & $13.294,51$ \\
\hline IRSKA & $\mathrm{DA}$ & DA & $\mathrm{DA}$ & $\mathrm{NE}$ & $\mathrm{DA}$ & $69.330,69$ \\
\hline ITALIJA & DA & $\mathrm{DA}$ & $\mathrm{DA}$ & DA & DA & $31.952,98$ \\
\hline LATVIJA & $\mathrm{DA}$ & $\mathrm{DA}$ & DA & DA & DA & $15.594,29$ \\
\hline LITVA & DA & $\mathrm{DA}$ & $\mathrm{DA}$ & $\mathrm{NE}$ & $\mathrm{DA}$ & $16.680,68$ \\
\hline LUKSEMBURG & $\mathrm{DA}$ & $\mathrm{DA}$ & $\mathrm{DA}$ & $\mathrm{NE}$ & $\mathrm{DA}$ & $104.103,04$ \\
\hline MADŽARSKA & $\mathrm{DA}$ & DA & $\mathrm{DA}$ & $\mathrm{DA}$ & $\mathrm{DA}$ & $14.224,85$ \\
\hline MALTA & $\mathrm{DA}$ & $\mathrm{DA}$ & $\mathrm{DA}$ & I & I & $26.945,98$ \\
\hline NEMČIJA & $\mathrm{NE}$ & $\mathrm{NE}$ & DA & DA & $\mathrm{NE}$ & $44.469,91$ \\
\hline NIZOZEMSKA & DA & $\mathrm{DA}$ & $\mathrm{NE}$ & $\mathrm{DA}$ & I & $48.223,16$ \\
\hline POLJSKA & $\mathrm{DA}$ & DA & $\mathrm{DA}$ & $\mathrm{DA}$ & $\mathrm{DA}$ & $13.811,66$ \\
\hline PORTUGALSKA & $\mathrm{DA}$ & DA & $\mathrm{DA}$ & $\mathrm{DA}$ & $\mathrm{DA}$ & $21.136,30$ \\
\hline ROMUNIJA & $\mathrm{DA}$ & $\mathrm{DA}$ & DA & DA & I & $10.813,72$ \\
\hline SEVERNA MAKEDONIJA & $\mathrm{DA}$ & $\mathrm{DA}$ & $\mathrm{DA}$ & $\mathrm{NE}$ & $\mathrm{NE}$ & $5.442,61$ \\
\hline SLOVAŠKA & $\mathrm{DA}$ & $\mathrm{DA}$ & $\mathrm{NE}$ & $\mathrm{DA}$ & $\mathrm{DA}$ & $17.604,95$ \\
\hline SLOVENIJA & $\mathrm{DA}$ & $\mathrm{DA}$ & DA & $\mathrm{DA}$ & $\mathrm{DA}$ & $23.597,29$ \\
\hline SRBIJA & $\mathrm{DA}$ & $\mathrm{DA}$ & $\mathrm{DA}$ & $\mathrm{NE}$ & $\mathrm{DA}$ & $5.900,04$ \\
\hline ŠPANIJA & $\mathrm{DA}$ & $\mathrm{DA}$ & $\mathrm{DA}$ & $\mathrm{DA}$ & $\mathrm{DA}$ & $28.156,82$ \\
\hline ŠVEDSKA & $\mathrm{DA}$ & DA & $\mathrm{DA}$ & DA & $\mathrm{DA}$ & $53.442,01$ \\
\hline VELIKA BRITANIJA & $\mathrm{DA}$ & DA & $\mathrm{NE}$ & $\mathrm{DA}$ & $\mathrm{DA}$ & $39.720,44$ \\
\hline
\end{tabular}

Tabela 1: Zakonska ureditev zasebnega varovanja v 32 evropskih državah 


\begin{tabular}{|c|c|c|c|c|}
\hline \multicolumn{5}{|l|}{ JAVNA NAROČILA } \\
\hline DRŽAVA & $\begin{array}{c}\text { Obstaja } \\
\text { zakonodaja, } \\
\text { ki ureja javno } \\
\text { naročanje }\end{array}$ & $\begin{array}{l}\text { Obstajajo merila } \\
\text { kakovosti za } \\
\text { naročanje storitev } \\
\text { zasebnega varovanja }\end{array}$ & $\begin{array}{l}\text { Vsebina ponudbe } \\
\text { zasebnovarnostnih } \\
\text { podjetij, ki sodelujejo } \\
\text { na javnih naročilih }\end{array}$ & $\begin{array}{l}\text { Glavni kriterij za izbiro ponudnika } \\
\text { storitev zasebnega varovanja }\end{array}$ \\
\hline AVSTRIJA & DA & DA & l & KAKOVOST \\
\hline BELGIJA & DA & l & l & l \\
\hline BOLGARIJA & $\mathrm{DA}$ & DA & l & KAKOVOST \\
\hline BOSNA IN HERCEGOVINA & $\mathrm{DA}$ & $\mathrm{DA}$ & PONUDBA STORITEV & RAZMERJE KAKOVOSTI IN CENE \\
\hline CIPER & DA & NE & l & l \\
\hline ČEŠKA & $\mathrm{DA}$ & NE & I & l \\
\hline ČRNA GORA & DA & l & l & I \\
\hline DANSKA & DA & l & PONUDBA STORITEV & l \\
\hline ESTONIJA & DA & $\mathrm{DA}$ & PONUDBA STORITEV & RAZMERJE KAKOVOSTI IN CENE \\
\hline FINSKA & DA & DA & I & l \\
\hline FRANCIJA & $\mathrm{DA}$ & $\mathrm{NE}$ & l & I \\
\hline GRČIJA & DA & DA & I & 1 \\
\hline HRVAŠKA & DA & $\mathrm{DA}$ & l & KAKOVOST IN EKONOMSKA DONOSNOST \\
\hline IRSKA & $\mathrm{DA}$ & $\mathrm{DA}$ & l & l \\
\hline ITALIJA & $\mathrm{DA}$ & $\mathrm{DA}$ & l & l \\
\hline LATVIJA & $\mathrm{DA}$ & $\mathrm{DA}$ & OSNOVE & CENA \\
\hline LITVA & $\mathrm{DA}$ & $\mathrm{DA}$ & l & 1 \\
\hline LUKSEMBURG & DA & $\mathrm{DA}$ & l & CENA \\
\hline MADŽARSKA & $\mathrm{DA}$ & $\mathrm{DA}$ & PONUDBA STORITEV & CENA IN EKONOMIČNOST \\
\hline MALTA & DA & l & l & 1 \\
\hline NEMČIJA & DA & $\mathrm{DA}$ & l & CENA \\
\hline NIZOZEMSKA & $\mathrm{DA}$ & $\mathrm{NE}$ & l & CENA IN KAKOVOST \\
\hline POLJSKA & $\mathrm{DA}$ & $\mathrm{NE}$ & l & RAZMERJE KAKOVOSTI IN CENE \\
\hline PORTUGALSKA & $\mathrm{DA}$ & l & PONUDBA STORITEV & CENA \\
\hline ROMUNIJA & $\mathrm{DA}$ & l & l & CENA \\
\hline SEVERNA MAKEDONIJA & $\mathrm{NE}$ & $\mathrm{NE}$ & l & l \\
\hline SLOVAŠKA & $\mathrm{DA}$ & $\mathrm{DA}$ & OSNOVE & RAZMERJE KAKOVOSTI IN CENE \\
\hline SLOVENIJA & DA & DA & PODROBNO & CENA, ZAKONITOST, STROKOVNOST \\
\hline SRBIJA & DA & NE & l & RAZMERJE KAKOVOSTI IN CENE \\
\hline ŠPANIJA & DA & DA & l & I \\
\hline ŠVEDSKA & $\mathrm{DA}$ & $\mathrm{DA}$ & l & RAZMERJE KAKOVOSTI IN CENE \\
\hline VELIKA BRITANIJA & & NE & I & I \\
\hline
\end{tabular}

Tabela 2: Pregled urejenosti sistema javnega naročanja v 32 evropskih državah 
Kratek pregled urejenosti področja zasebnega varovanja v dvaintridesetih evropskih državah

V nadaljevanju predstavljamo kratek pregled urejenosti področja zasebnega varovanja v 32 državah članicah, kot si sledijo po abecednem redu.

\section{AVSTRIJA}

Posebnost za Avstrijo je, da za podjetja, ki opravljajo zasebnovarnostne storitve, ni posebne zakonodaje. Panoga in poklic sta regulirana, nimajo pa posebnega akta o zasebnem varovanju. Dejavnosti odobri Ministrstvo za gospodarstvo in delo. Podjetja, ki se želijo ukvarjati z zasebnim varovanjem, potrebujejo obrtno dovoljenje (Zemljič, 2010). Vsi zakoni niso javno dostopni (za dostop moraš imeti uporabniški račun). Člani skupine ponudnikov varnostnih storitev so na trgu razvili lasten program usposabljanja, ki ga je akreditiral avstrijski certifikacijski organ (özs). Vsak novi zaposleni mora opraviti to usposabljanje (Verband der Sicherheitsunternehmen Österreichs, n. d.). Varnostno osebje lahko ustavi osebo, uporabi fizično silo, pomaga v stiski, opravi preiskavo ali zaseže predmete. Zakon, ki ureja industrijo zasebnega varovanja, ne dovoljuje oboroženih storitev zasebnega varovanja, razen če je podeljena posebna licenca (CoEss, 2013). Glavni viri prava za javna naročila $\mathrm{v}$ Avstriji so zvezna javna naročila (Bvergg) in Zvezni zakon o oddaji naročil na področju obrambe in varnosti (Bverggvs). Ključni cilj je zagotoviti poštene javne razpise s povečanjem kakovosti ponudnikov. Kar zadeva načelo najboljšega ponudnika, je določilo, da se storitve ne izbira samo po najnižji ceni. Izbira po najnižji ceni je dovoljena le $\mathrm{v}$ primeru standarda kakovosti primerljivega $\mathrm{z}$ drugimi ponudniki (Marboe, 2016).

\section{BELGIJA}

Belgija ima regulirano panogo zasebnega varovanja in tudi poklic. Pogojev za pridobitev posamezne licence ne zasledimo. Imajo pa licenco za varovanje letališč, licenco za prevoz denarja, licenco za zagotavljanje pomorske varnosti, licenco za varovanje kritične infrastrukture, licenco za zagotavljanje požarne varnosti, licenco za varovanje posesti (notranje varnosti), licenco za nadzor vrat in licenco za zaščito komercialnih plovil (CoEss, 2013). 
Pogoji za opravljanje poklica so podobni kot v Sloveniji: kandidat mora biti državljan EU in v eni od članic imeti stalno prebivališče, ne sme biti pripadnik policije zadnjih 5 let, imeti mora najmanj 21 let, licenco s strani MNZ ter pozitivno mnenje s strani Ministrstva za pravosodje, opravljene psihološke in zdravniške teste, opravljen tečaj usposabljanja ter varnostno preverjanje (CoEss, 2013). V Belgiji zasebnovarnostna podjetja varujejo tudi kritično infrastrukturo. Poznajo klasična pooblastila, zasledimo pa tudi nekaj posebnosti, kot denimo, da so usposobljeni za boj proti piratom in da lahko pri tem delu uporabljajo vojaško orožje. Zasebnovarnostna podjetja $\mathrm{v}$ Belgiji prisegajo na visoko integriteto svojih zaposlenih in dobro organiziranost ter sposobnost delovanja $\mathrm{v}$ timu.

\section{BOLGARIJA}

Bolgarija ima v veljavi zakon o Zasebnem varovanju in Zakon o javnem naročanju. Zakon o zasebnem varovanju ureja panogo in poklic zasebnega varovanja. Licenciranje družb za zasebno varovanje je obvezno. Pristojna nacionalna organa, ki izdata dovoljenje, sta Policija in Ministrstvo za notranje zadeve. Kvalifikacija za poklic varnostnika se pridobi v Zavodu za poklicno izobraževanje in usposabljanje. Dejavnost zasebnega varovanja se izvaja neoboroženo ali oboroženo. Varnostno osebje lahko osebe identificira, pregleda in uporabi fizično silo. $\mathrm{V}$ hujših primerih lahko uporabi tudi strelno orožje (Zakon za častnata ohranitelna deynost, 2018). $\mathrm{Z}$ zakonom o javnem naročanju se določajo pogoji za oddajo javnih naročil v primeru gradenj, blaga ali storitev in pogoji za natečaje naročnikov. Zakon posebej ne omenja storitev zasebnega varovanja (Zakon za obštestvenite porăčki, 2016). Javna naročila za storitve zasebnega varovanja se oddajajo na podlagi razmerja med kakovostjo in ceno. V Bolgariji poudarjajo kakovost zasebnovarnostnih storitev, da bi s tem zmanjšali nepošteno konkurenco na trgu (CoEss in UnI-Europa, 2014).

\section{BOSNA IN HERCEGOVINA}

Največja problematika Bosne in Hercegovine je zakonodaja, ki še vedno ni dokončno in pravilno opredeljena, razlog za to pa je teritorialna ločenost ozemlja na tri dele. Še močnejše razloge za neurejenost zakonodaje bi lahko iskali v zgodovini države in problematiki pojava vojn na tem območju. Fizične in tehnične storitve 
so $\mathrm{v}$ Bosni in Hercegovini regulirane $\mathrm{z}$ Zakonom o agencijah in zaščito oseb ter lastnine (Law of Agencies for protection of persons and property, 2002). Pogoji za pridobitev licence: kandidat mora biti državljan $\mathrm{BiH}$; imeti dovoljenje za izvajanje varnostnih storitev; biti telesno in duševno sposoben opravljati varnostne naloge; pridobiti vsaj srednješolsko izobrazbo (osebje na področju tehnične zaščite mora imeti ustrezno tehnično izobraževanje); zoper osebe ne smejo obstajati nobene kazenske evidence ali postopki; oseba nikoli ni smela biti diskvalificirana iz mednarodne policije ali odpuščena iz vojaške službe; najnižja dovoljena starost je 18 let (vodstvo zasebnovarnostnega podjetja, starost 22 let) (CoEss, 2013).

Merila kakovosti za nakup storitev zasebnega varovanja so zapisana v Zakonu o javnih naročilih Bosne in Hercegovine v 22. in 26. členu. V 34. členu pa je zapisan potek izbora javnega naročila. Bosna in Hercegovina se odloča na podlagi najcenejšega ponudnika ali pa na podlagi nujnosti, uporabnosti ali kakovosti pogodbe. Razlikovanje je podrobneje opredeljeno v Zakonu o javnih naročilih Bosne in Hercegovine, in sicer v 34. členu, merila za dodelitev pogodbe (Law of public procurement for Bosnia and Herzegovina, 2004).

\section{CIPER}

Panoga zasebnega varovanja in poklic varnostnika sta regulirana. Družbe zasebnega varovanja so dolžne vsako leto predložiti seznam dejavnosti in dogodkov, $\mathrm{v}$ katerih je interveniralo njihovo osebje. Zakonodaja predvideva nadzor in kontrolo uradov za zasebno varovanje in njihovega osebja. $\mathrm{V}$ skladu $\mathrm{z}$ zakonom podjetja zasebnega varovanja in tudi njihove zaposlene nadzoruje in preverja policija (Generally about Law, 2007). Zakonodaja za zasebna podjetja za varovanje zagotavlja, da lahko opravljajo storitve in dejavnosti za boj proti piratstvu na komercialnih plovilih, ki plujejo pod zastavo svojih držav. Zasebni varnostniki imajo pristojnosti in pooblastila, enaka pooblastilom vsakega državljana. Ne smejo opraviti iskanja in zasega (CoEss, 2013).

\section{ČEŠKA}

Češka Republika nima reguliranega področja zasebnega varovanja (Button, 2007). Zakon je že leta v pripravi, vendar je oviran zaradi različnih političnih interesov. Posebnih omejitev za delo 
na tem področju ni. Osebe (zaposleni, menedžerji) morajo biti stare 18 ali več let. Zasebno varnostno osebje mora biti pred začetkom dela varnostno preverjeno (postopek varnostnega preverjanja ni javno dostopen). Pristojnosti zasebnih varnostnikov se ne razlikujejo dosti od pristojnosti državljanov (CoEss, 2004; CoEss, 2013). V Češki Republiki imajo Zakon o javnem naročanju, ki vsebuje posebno poglavje za področje varnosti in obrambe (Zákon o zadávání veřejných zakázek, 2016).

\section{ČRNA GORA}

Črna Gora ima Zakon o zasebnem varovanju in Zakon o javnem naročanju. Oba zakona sta podobna zakonom Slovenije. V Zakonu o zasebnem varovanju lahko zasledimo, da sta panoga in poklic regulirana. Za storitve zasebnega varovanja se zahtevajo določeni pogoji, prav tako se zahteva tudi strokovna usposobljenost. Program usposabljanja predpiše pristojno ministrstvo, osebe pa so predhodno varnostno preverjene. Varnostniki imajo možnost izvajanja določenih ukrepov, ki zavzemajo ugotavljanje identitete osebe, opozarjanje, pregled osebe/predmetov in vozila, pridržanje, zavarovanje kraja dogajanja, uporabo fizične sile, uporabo psa ter strelnega orožja. Na zasebnovarnostna podjetja je država prenesla tudi varovanje nekatere kritične infrastrukture (Zakon o zaštiti lica i imovine, 2013). Z Zakonom o javnem naročanju določajo pogoje, način in postopek nabave blaga, storitve ter dobave del. V zakonu ni zaslediti posebnih omenjanj zasebnega varovanja (Zakon o javnim nabavkama, 2017).

\section{DANSKA}

Danska ima zasebno varovanje opredeljeno v Zakonu o varnostnih storitvah. Ta opredeljuje licence, posebnih pooblastil in pristojnosti pa varnostniki nimajo (Zzas V-B, 2oog). Na varnostnem področju se iščejo vse priložnosti, da se razreši policijo in da se naloge prenesejo na področje zasebnovarnostne industrije. Eno izmed pomembnih objektov, ki ga varujejo varnostniki, je letališče Kopenhagen (CoEss, 2013). Javno naročanje je opredeljeno v Zakonu o javnih naročilih, ki izhaja iz klasične direktive o javnih naročilih (Udbudsportalen, n. d.). Varnostna podjetja izvajajo varovanje na področjih varovanja gostov, kontroli vhoda in izhoda, varovanju trgovin ter hotelov, varnostnih dogodkov in zagotavljajo osebno varnost (MF Security solutions, n. d.). 


\section{ESTONIJA}

Zasebno varovanje je $\mathrm{v}$ Estoniji regulirano $\mathrm{z}$ Zakonom o varnosti, ki je bil sprejet leta 2003 (Coess, 2011). Pogoji za pridobitev licence so: oseba mora biti estonski državljan, star najmanj 19 let, z dokončano osnovnošolsko izobrazbo ali kvalifikacijo za varnostnika ali oseba, ki je dobila stalno pravico do prebivanja v Estoniji ali ki ji je bilo izdano dovoljenje za prebivanje za rezidenta za daljši čas; oseba mora biti usposobljena na ravni, določeni z zakonom, sposobna opravljati dolžnosti varnostnika v smislu morale, telesne pripravljenosti in zdravja. Varnostnik, ki zagotavlja varnost za javni dogodek, osebno zaščito ali transakcije z gotovino in vrednostnimi papirji, mora biti star vsaj 21 let (CoEss, 2011). V Estoniji so predpisani pogoji za pridobitev poklica zapisani v Zakonu o varnosti (Riigi Teataja, 2010). V Estoniji poznajo tri vrste odločanj za izbiro javnega naročila. Gre za kvalitativna merila, socialna merila v razpisani dokumentaciji, pogodbene cene in stroške. Kot najbolj pomembno pri izbiri ponudnika za opravljanje zasebnovarnostnih storitev ocenjujejo razmerje med kakovostjo in ceno javnega naročila. Izberejo najbolj kakovostnega z najnižjo ekonomsko ceno (Riigi Teataja, 2019).

\section{FINSKA}

Zasebno varovanje na Finskem je regulirano $\mathrm{z}$ »Act on Private Security Services «, ki ureja področje varovanja in varnosti (Meacher v Van Steden in Sarre, 2007). Policija je pristojna za podeljevanje licenc za opravljanje zasebnega varovanja. Licence se podeljujejo za naslednje poklice: čuvaj, začasen čuvaj, varnostnik, upravljavec varnosti in začasni upravljavec varnosti (CoEss, 2004; CoESs, 2013). Pogoji za opravljanje katerega koli poklica so: starost, višja od 18 let, opravljeno usposabljanje za določen poklic (ter pridobitev certifikata) in poznavanje nacionalnega jezika. Pred tem mora oseba opraviti še zdravniški pregled. Oseba ne sme biti obsojena za kazniva dejanja (CoEss, 2013). Zasebnovarnostna podjetja varujejo kritično infrastrukturo pred kibernetskimi grožnjami (Ministry of the Interior, Finland National Risk Assessment 2015 v Pursiainen, 2018; Internal security v Pursiainen, 2018). Zakonodaja o javnem naročanju na Finskem je urejena z več zakoni. Varovanje je urejeno drugače kot pri nas, saj imajo za to področje poseben zakon, ki ureja področje obrambe in varnosti (Kuusniemi-Laine, Lähde, NordenstrengSarkamo in Kaariste, 2016). Uspešna so podjetja, ki poleg varnostnih 
storitev ponujajo tudi druge storitve (Confederation of European Security Services v Santonen in Paasonen, 2015).

\section{FRANCIJA}

Zasebnovarnostna industrija in poklic varnostnika sta v Franciji regulirana. V zakonu je določeno, katere licence lahko pridobijo podjetja in kakšni so pogoji za opravljanje poklica varnostnika. Posebnost, ki se veže na pooblastila je, da v nobenem primeru varnostnik ne sme uporabiti sredstev za vklepanje ali vezanje in plinskega razpršilca. Orožje je sicer dovoljeno uporabljati, vendar le pri prevozu denarja. Država je na zasebnovarnostna podjetja prenesla varovanje letališč in pristanišč (CoEss, 2013). Pri javnih naročilih se upošteva Kodeks o javnih naročilih iz leta 2019 (Kodeks javnih naročil, 2019).

\section{GRČIJA}

Imajo zakonodajo s področja javnega naročanja, v kateri je tudi poudarjeno, da sama cena ne sme biti ključni element pri izbiri izvajalca za zagotavljanje varnosti (Direktiva 81, 2009). Zasebnovarovanje in poklic varnostnika sta regulirana dejavnost. Varnostniki prevzemajo tudi varovanje kritične infrastrukture. Imajo zelo natančen postopek, ki določa, kdaj oseba ne more postati varnostnik. Pri svojem delu nimajo posebnih pooblastil. Njihova zakonodaja določa tudi, da se lahko orožje uporablja zgolj in samo ob varovanju letališč in pri prevozu denarja (CoEss, 2013).

\section{HRVAŠKA}

$\mathrm{Na}$ Hrvaškem imajo Zakon o zasebnem varovanju in Zakon o javnem naročanju. Dejavnosti zasebnega varovanja lahko opravljajo pravne osebe, ki so registrirane za opravljanje dejavnosti zasebnega varovanja. Opravljajo lahko naloge tehničnega in fizičnega varovanja. Delo lahko opravlja oseba, ki izpolnjuje določene pogoje, kot so npr. prebivališče, starost, izobrazba, psihofizična sposobnost, nekaznovanost, strokovni izpit, in je varnostno preverjena. Med izvajanjem dela lahko varnostniki izvajajo določene ukrepe, in sicer identificirajo osebe, opozarjajo, omejijo svobodo, pregledajo osebe/predmete, uporabijo psa in fizično silo ter strelno orožje itd. (Zakon o privatnoj zaštiti, 2003). 
Javno naročanje opredeljujejo kot naročanje blaga, gradenj ali storitev, ki jih naroči eden ali več naročnikov iz gospodarskih subjektov. V zakonu navajajo pravila in postopke javnega naročanja (Zakon o javnoj nabavi, 2016). Trudijo se zatreti trend najnižjih cen. Cene zasebnovarnostnih storitev so pred leti začele padati pod realne stroške. Posledično so povečali zahteve za dvig kakovosti, strokovnosti in števila varnostnikov (Antić, 2017).

\section{IRSKA}

$\mathrm{Na}$ Irskem kazenska evidenca ni takojšnja ovira v postopku pridobivanja licence, saj ima Psa (Zasebno varnostni organ na Irskem) diskrecijsko pravico pri odločanju, ali bo osebi s kriminalno zgodovino izdala dovoljenje (Private Security (Licensing and Standards) Regulations, 2005). V državi je dovoljena uporaba službenih psov, ni pa dovoljeno nošenje orožja. Osebo lahko tudi pridržijo. Vse vodje zasebnovarnostnih služb so bivši uslužbenci Garde (Policije). $\mathrm{O}$ javnem naročanju ni veliko podatkov. Podano je le, da morajo nekatere koncesije pri javnem naročanju, ki zajemajo obrambne in varnostne vidike, biti tajne. Irski sistem javnih naročil urejajo Evropske skupnosti (pogodbe o oddaji javnih naročil), Predpisi 2006 - Si 329/2006 in Evropske skupnosti (dodelitev pogodb s strani gospodarskih družb) 2007 - Si 50/2007, Evropska unija (dodelitev pogodb) v zvezi z obrambo in varnostjo) - Si 62/2012, obstajajo pa tudi druge smernice za urejanje pragov itd. Organ za javna naročila je Urad za javna naročila, ki se nahaja v okviru Oddelka za javne izdatke in reforme. V 95\% se odločijo za najcenejšega ponudnika (Izbira ponudbe najboljše vrednosti - priročnik za organizacije pri oddaji naročil za storitve zasebnega varovanja, 2000).

\section{ITALIJA}

Za področje zasebnega varovanja je pristojno Ministrstvo za notranje zadeve in »Provincial Prefect«. Zakonska podlaga, ki ureja tudi področje zasebnega varovanja, regulira področje javne varnosti. Licence za področje zasebnega varovanja v Italiji podeljuje »Provincial Prefect «. Pogoji za opravljanje poklica so opravljeno varnostno preverjanje (pregled kazenske evidence opravi Ministrstvo za pravosodje), minimalna starost 18 let (tudi za varnostnega menedžerja) in opravljeno usposabljanje (psihični ter fizični testi). Posebna pooblastila, ki jih imajo zasebni varnostniki v Italiji, so: 
odvzem osebne izkaznice, uporaba službenega psa in uporaba službenega konja. Službeni pes in konj se uporabljata tudi pri varovanju kritične infrastrukture, za njuno uporabo osebje ne potrebuje posebnih usposabljanj. Zasebnovarnostna podjetja torej varujejo kritično infrastrukturo - opravljajo pomožne varnostne storitve na letališčih, pristaniščih, postajah, preventivno delujejo na morju proti piratstvu (CoEss, 2013). V Italiji je javno naročanje urejeno z zakonom Code of Public Contracts (Bucchi in Casini, 2016). prav tako njihova zakonodaja temelji na direktivah in usmeritvah Evropske unije, ki ima določena merila kakovosti zasebnega varovanja (Bucchi in Casini, 2016). Le $15 \%$ zasebnovarnostnih podjetij se ukvarja izključno z zasebnim varovanjem. Več kot $85 \%$ podjetij poleg dejavnosti zasebnega varovanja ponuja tudi druge storitve, ki se ne nanašajo na področje varnosti (CoEss, 2013).

\section{LATVIJA}

Zasebno varovanje je v Latviji regulirano s tremi zakoni, in sicer: Zakon o varnostniku, Zakon o gibanju orožja in posebnih sredstev ter Detektivsko pravo (CoEss, 2013). V Latviji je osnovni pogoj za pridobitev poklica uspešno opravljeno obvezno usposabljanje, ki traja 160 ur, potrebno je opraviti pregled in posledično prejeti potrdilo o uspešnem pregledu, obvezno je plačilo licence ter nekaj vhodnih omejitev: kandidat ne sme biti obsojen za kaznivo dejanje, ne sme imeti duševnih bolezni in biti odvisen od mamil ali alkohola (LikUMi LV, 2006). Postopek varnostnega preverjanja je takšen, da pregledajo kriminalno zgodovino osebe (CoEss, 2011). V Latviji je odločanje za izbiro javnega naročila zapisano v Zakonu $\mathrm{o}$ javnih naročilih, in sicer $\mathrm{v}$ 51. členu, ki govori o merilih za ocenjevanje ponudb javnih naročil (LIKUMI, 2017).

\section{LITVA}

Licenciranje podjetij za zasebno varovanje je po zakonu obvezno. Pristojni nacionalni organ, ki izda dovoljenje, je načelnik policije (CoEss, 2013). Za zasebne varnostnike, ki zagotavljajo oborožene storitve zasebnega varovanja, je potrebna posebna licenca. Pogoji so podobni kot pri nas, le da so pogoji, kdo ne sme biti varnostnik, strožje določeni. Litovski sistem javnih naročil urejajo zakon o javnih naročilih (2006) in dodatni predpisi, ki so jih uvedli vlada, Ministrstvo za okolje, Ministrstvo za gospodarstvo in Urad za javna 
naročila (European Public Accountability Mechanism, 2019). Več podatkov o javnem naročanju storitev zasebnega varovanja ni dostopnih.

\section{LUKSEMBURG}

V Luksemburgu se zasebni varnostniki imenujejo agenti (Sociétés de surveillance et de gardiennage, 2014). Nošenje uniforme je prepuščeno izbiri podjetij, razen agentov za prevoz gotovine, ki morajo nositi uniformo. Ti agenti lahko nosijo tudi orožje (CoEss, 2013). Edini razlikovalni znak, ki ga morajo nositi vsi zasebni varnostniki, je legitimacijska kartica, ki je formalno določena z zakonom. Politika enakih možnosti (Eo) je v veljavi tudi v industriji zasebnega varovanja. V luksemburgu se v $100 \%$ na javnih naročilih odločijo za najcenejšega ponudnika (Izbira ponudbe najboljše vrednosti - priročnik za organizacije pri oddaji naročil za storitve zasebnega varovanja, 200o).

\section{MADŽARSKA}

$\mathrm{Na}$ Madžarskem je zasebno varovanje regulirano z Zakonom o pravilih o osebnem in premoženjskem varstvu ter o dejavnostih zasebnih preiskovalcev, ki je bil sprejet leta 2005 (CoEss, 2013). Varnostniki na Madžarskem imajo posebej določena pooblastila, ki so določena $\mathrm{v}$ Zakonu o pravilih o osebnem in premoženjskem varstvu ter o dejavnostih zasebnih preiskovalcev, in sicer v 26. členu, ki govori o pravilih za osebe, ki izvajajo osebne in premoženjske dejavnosti (Wolters Kluwer, 2005). Na Madžarskem so v Zakonu o javnih naročilih od 69. do 74. člena zapisana merila za vloge za zbiranje ponudb in udeležbo. Merila kakovosti za določitev nakupa storitev zasebnega varovanja so opredeljena v zakonu (KözbESZERZÉSI HATÓsÁG, 2019).

\section{MALTA}

Zakon, ki ureja industrijo zasebnega varovanja, ne dovoljuje oboroženih storitev zasebnega varovanja. Zasebna varnostna podjetja lahko opravljajo storitve in dejavnosti za boj proti piratstvu na krovu trgovskih plovil, ki plujejo pod zastavo svoje države. Zasebni varnostniki ali policisti lahko opravljajo druga dejanja, ki presegajo običajne pristojnosti državljanov (pooblastilo/aretacija, dokler ne 
prispe policija) (CoEss, 2013). Pogoji za pridobitev poklica so bolj izostreni kot drugje.

\section{NEMČIJA}

Nemčija nima specifične zakonodaje o zasebnem varovanju, nimajo nekih konkretnih licenc in opredelitev o umestitvi zasebnovarnostne industrije. Pooblastila so razdeljena na dve večji skupini, in sicer prva skupina so pooblastila $\mathrm{z}$ uporabo zmerne fizične sile za izvrševanje konkretnih nalog, druga skupina pa pooblastila, ki zajemajo pregled vozila. Varnostna podjetja opravljajo kontrole oseb in prtljage na letališčih, varnostne ukrepe v elektrarnah in drugih ustanovah kritične infrastrukture kakor tudi na nepremičninah vojske. Celotna zasebnovarnostna dejavnost temelji na tem, da: »... bilo bi zaželeno, da se uporablja ... ali ... bi bilo zaželeno, da se izvaja ... (Lastno pravo za varnostno industrijo, 2018) ni pa obveznost, kot recimo v Sloveniji.

Javna naročila so opredeljena $\mathrm{z}$ Zakonom o javnih naročilih. Za najem zasebnovarnostnega podjetja pa se odločajo na podlagi cene in ne upoštevajo drugih meril, kot sta zanesljivost ter kakovost. Ključna področja pri izbiri varnostnega podjetja so: izbira in usposobljenost varnostnega osebja; vodenje naročil ter operativno vodenje; infrastruktura naročil in uspešnost podjetja (G. I. B. INFO, n. d.).

\section{NIZOZEMSKA}

Stroški za zasebno varovanje so zelo visoki, kar je poudarjeno predvsem v Zakonu o javnem naročanju. Zasebna dejavnost in poklic varnostnika sta regulirana. Na Nizozemskem ponujajo tudi storitve varovanja otrok, varovanja hostes in kot zanimivost storitev varnostnika ter VIP-voznika hkrati. Varnostniki pri svojem delu nimajo nobenih posebnih pooblastil, saj imajo iste pravice kot vsi ostali civilisti. Pri svojem delu prav tako ne smejo nositi orožja ali lisic (Coess, 2013). Pri javnem naročanju vlada na podlagi konkurence išče najnižjo ceno ali, če obstajajo druga merila, ekonomsko najugodnejšo ponudbo, ki pa ni nujno, da je tudi najkakovostnejša (VLAANDEREN, n. d.). 


\section{POLJSKA}

Zasebno varovanje je pod okriljem Ministrstva za notranje zadeve. Nadzor nad zasebnim varovanjem ima tudi vodja policije. Zasebno varovanje na Poljskem je regulirano $\mathrm{z}$ »Act on the Protection of People and Property« iz leta 1997 (Coess, 2013). Z letom 2014 je prišlo do zakonskih sprememb področja zasebnega varovanja (pridobitev licence za opravljanje poklica Zasebni varnostnik ni več obvezna). Pogoji za opravljanje dejavnosti so: odsotnost kriminalne preteklosti, starost vsaj 18 let (menedžerji 21 let), srednješolska izobrazba in opravljeno usposabljanje ( $245 \mathrm{ur}$ ). Posebna pooblastila, ki jih ima zasebnovarnostno osebje, se nanašajo na uporabo fizične sile, lisic, palice (tonfe) in strelnega orožja, preverjajo lahko posameznikovo identiteto ter pogledajo $\mathrm{v}$ osebno izkaznico. Uporaba službenega psa je dovoljena s strani za to usposobljenih oseb (CoEss, 2013). Področje javnega naročanja je urejeno z zakonom »Public Procurement Law» (Ec.europa.eu., n. d.).

\section{PORTUGALSKA}

Zasebno varovanje in poklic varnostnika sta regulirana. Varnostniki so še posebej usposobljeni za boj proti piratom, pri katerem pa lahko uporabljajo tudi vojaško orožje. Na Portugalskem imajo tudi posebno licenco za varovanje letališč in pristanišč, s čimer so prevzeli del varovanja kritične infrastrukture namesto policije (CoEss, 2013). Javna naročila so urejena v skladu s Kodeksom o javnih naročilih, št. 20/2008 (Kodeks o javnih naročilih, 2008).

\section{ROMUNIJA}

Področje zasebnega varovanja je $\mathrm{v}$ Romuniji opredeljeno $\mathrm{v}$ Zakonu 333, ki je bil sprejet leta 2003 (Zakon 333, 2003). Natančno so opredeljene licence, pogoji za opravljanje poklica in pooblastila varnostnikov. Varovanje se opravlja v bankah, zasebnih hišah, lekarnah in trgovinah, gradbiščih, verskih ustanovah ter tovarnah in podjetjih (CoEss, 2013). Eno izmed pomembnih objektov, ki ga varujejo varnostniki, je jedrska elektrarna »Cernavodă« (Replica, 2011). Javno naročanje je opredeljeno v Zakonu o javnem naročanju ter v Zakonu št. 99. / 2016 - (Zakon o sektorskih javnih naročilih, 2016). Pri izbiri zasebnovarnostnega podjetja se odločajo glede na ceno in ne na kakovost. Na podlagi tega pa že iz prakse ugotavljajo, da jih poceni storitev lahko veliko stane. 


\section{SEVERNA MAKEDONIJA}

Zasebnovarnostna industrija je opredeljena v Zakonu za privatno obezbeduvanje. Natančno so opredeljene vrste licenc, pogoji za pridobitev poklica ter pooblastila (Zakon za privatno obezbeduvanje, 2013). V Makedoniji so zakonodajo o zasebnem varovanju nekoliko povzeli po slovenskih predpisih. Predlog o varovanju kritične infrastrukture s pomočjo varnostnega osebja je bil predlagan, vendar ni bil nikoli sprejet (Kunovski, 2017). Javno naročanje v Makedoniji ni zakonsko opredeljeno in omenjeno področje ne poteka tako kot pri nas. Bistveno vlogo pri javnem naročanju ima Komora Republike Makedonije, ki opravlja posebne naloge (CoEss, 2013).

\section{SLOVAŠKA}

V Slovaški je zasebno varovanje regulirano z Zakonom o opravljanju storitev zasebnega varovanja in o spremembah ter dopolnitvah nekaterih zakonov (Zakon o zasebnem varovanju). Delo varnostnikov imajo razširjeno na kritično infrastrukturo. Javno naročanje je regulirano tako kot $v$ Sloveniji, vendar imajo Urad javne uprave za javno naročanje in $v$ njem svet, ki se ukvarja $\mathrm{Z}$ varovanjem javnih naročil. Pristojnosti in pooblastila varnostnikov so, da lahko zadržijo storilca do prihoda policije in imajo dovoljenje za zaseg (Private Security Law Slovakia, 2005). Ponudbe javnih naročil ocenijo na podlagi najboljše vrednosti za denar, pristop stroškovne učinkovitosti, pristop do stroškov, najnižja cena (SLOV-LEX právny informačný portál, 2019).

\section{SLOVENIJA}

Zasebno varovanje je urejeno $\mathrm{z}$ Zakonom o zasebnem varovanju (2011). Prav tako ima omenjena dejavnost velik pomen pri varovanju kritične infrastrukture, saj varnostniki skrbijo za varnost $\mathrm{v}$ npr.: Nuklearni elektrarni Krško - NeK, skladiščih naftnih derivatov in Luki Koper.

Naloge, ki se nanašajo na zasebno varovanje, opravlja varnostno osebje, ki mora imeti veljavno licenco ter izpolnjevati pogoje za opravljanje teh nalog. Naloge so določene v skladu z zakonom. V zakonu so opredeljeni tudi sistem izdaje in uporabe službenih izkaznic, pooblastila ter ostale pristojnosti, ki jih ima varnostno osebje (Republika Slovenija: Ministrstvo za notranje zadeve, 2019). 
V Zakonu o javnem naročanju je opredeljeno področje javnega naročanja (Zakon o javnem naročanju, 2016). Prav tako se v Sloveniji glede izbire zasebnovarnostnega podjetja odločajo glede na ceno in ne na kakovost. Najpomembnejši dejavniki pri izbiri varnostnega podjetja so naslednji kriteriji: zakonitost, strokovnost, zmožnost izvajanja storitve, načrtovanje in cene storitve (Coess, n. d.).

\section{SRBIJA}

Republika Srbija ima v veljavi Zakon o zasebnem varovanju in Zakon o javnem naročanju. Po strukturi sta podobna zakonom v Sloveniji. Po Zakonu o zasebnem varovanju sta sama panoga in poklic regulirana. Za panogo se zahtevajo registriranje in določeni akti. Za poklic zahtevajo določeno izobrazbo, varnostni pregled, psihofizično sposobnost in strokovni izpit na pristojnem ministrstvu. Vse je odvisno od načina dela. Med izvajanjem dela lahko varnostnik preverja identiteto, prepove vstop/dostop do objekta, opozarja, zadrži in uporabi prisilna sredstva (Zakon o privatnom obezbeđenju, 2013). Zakon o javnem naročanju ureja načrtovanje javnih naročil, pogoje, način in postopek javnega naročanja. V samem zakonu ni izrecno zaslediti področja zasebnega varovanja (Zakon o javnim nabavkama, 2015). V Republiki Srbiji imajo razmere, $\mathrm{v}$ katerih se ponudbe pogosto dodelijo ponudniku, ki ponuja najnižjo ceno. Trudijo se zmanjšati trend in informirati javnost, da bi se storitve iskale glede na kakovost. Izvajalci storitev nimajo jasno določene kakovosti varnosti glede na ceno. Pomanjkanje je tudi pri preverjanju vpletenosti varnostnih vodij in ponudnikov storitev (CEAS, 2015).

\section{ŠPANIJA}

Zasebno varnostna industrija v Španiji je opredeljena z Zakonom Act 5/2014 on Private Security (Aproser, 2016). Natančno so opredeljene licence, pogoji za opredelitev poklica ter pooblastila varnostnikov. Za varovanje kritične infrastrukture skrbijo varnostniki, in sicer v jedrski elektrarni Trillo (Ballesteros R., 2016) in jedrski elektrarni Asco (Rovira, 2015). Javno naročanje je opredeljeno z Uredbo o javnem naročanju, katere namen je regulativni razvoj temeljne državne zakonodaje v zvezi s pogodbami o javni upravi in pogodbenimi akti (Splošna uredba javnega naročila, 2003). 


\section{ŠVEDSKA}

Švedska ima zelo natančno določen in strog program usposabljanja za varnostnike $\mathrm{z}$ različnih področij. Najprej mora osebje opraviti osnovni tečaj za varnostnika, potem pa se mora dodatno usposobiti, če želi varovati kritično infrastrukturo. Poklic in sama dejavnost zasebnega varovanja sta zakonsko regulirana (Coess, 2013). Postopka varnostnega preverjanja nismo zasledili. Omenjeno je le, da morajo biti varnostno preverjeni ravno zaradi zanesljivosti. V Švedski imajo tudi zakonodajo s področja javnega naročanja. Švedska podjetja se lahko najbolj pohvalijo s številnimi pridobljenimi certifikati in tako poudarijo tesno sodelovanje s strankami (Zakon o javnih naročilih 1145, 2016).

\section{VELIKA BRITANIJA}

Področje zasebnega varovanja ureja The Private Security Industry Act iz leta 2001 (CoEss, 2004; CoEss, 2013; Button, 2007; Van Steden in Sarre, 2007). Za pridobitev licence morajo prosilci podati podatke o psihičnem zdravju. Opravi se tudi varnostno preverjanje. Prosilec mora biti star vsaj 18 let (Coess, 2013). Za pridobitev licence ni pogoj, da oseba ne sme biti vpisana v kazensko evidenco, ampak ugotavljajo težo prestopka. Prosilec mora imeti dovoljenje za delo v Združenem kraljestvu (SIA, n. d.). Zasebnovarnostno osebje lahko pri svojem delu uporablja službenega psa in konja, dovoljena sta omejen pregled in zaseg, ostale pristojnosti so enake kot pri vseh državljanih. Zasebnovarnostna podjetja varujejo kritično infrastrukturo (CoEss, 2013). Javno naročanje za potrebe obrambe in varnosti je urejeno s posebno uredbo iz leta 2011 (Gatenby et al., 2016). 


\section{Zasebno varovanje v Sloveniji}

V Republiki Sloveniji je zasebno varovanje regulirana dejavnost. Zakon o zasebnem varovanju (»Zzasv-1", 2011) zasebno varovanje definira kot varovanje ljudi in premoženja na varovanem območju ali objektu pred poškodovanjem ali uničenjem. Storitve zasebnega varovanja se opravlja s pomočjo varnostnikov in $\mathrm{z}$ uporabo tehničnih sistemov. Storitve zasebnega varovanja v Sloveniji lahko kot pridobitno dejavnost za naročnika zagotavlja zgolj gospodarska družba ali posameznik, ki ima za to pridobljeno licenco in izpolnjuje pogoje za opravljanje tovrstne dejavnosti.

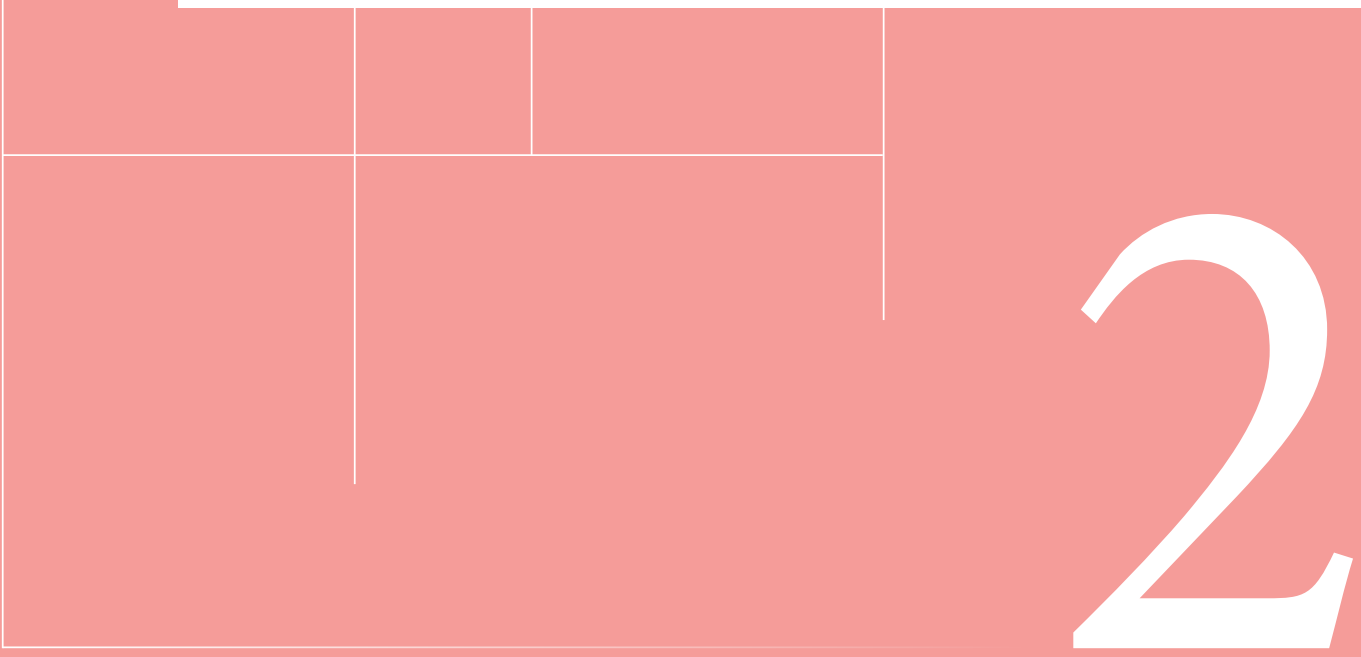


Zasebno varovanje zajema širok nabor dejavnosti, ki predstavljajo licence na področju zasebnega varovanja. Gospodarska družba ali podjetnik posameznik lahko pridobi naslednje licence:

a. varovanje ljudi in premoženja,

b. varovanje oseb,

c. prevoz in varovanje gotovine ter drugih vrednostnih pošiljk,

d. varovanje javnih zbiranj,

e. varovanje prireditev $\mathrm{v}$ gostinskih lokalih,

f. upravljanje $\mathrm{z}$ varnostno-nadzornim centrom,

g. načrtovanje sistemov tehničnega varovanja in izvajanje sistemov tehničnega varovanja (»Zakon o zasebnem varovanju [Zzasv-1]«, 2011).

Varnostno podjetje lahko pridobi licence glede na naslednje splošne pogoje, in sicer da:

- ima za nedoločen čas s polnim delovnim časom v delovnem razmerju varnostnega menedžerja, ki opravlja naloge odgovorne osebe za opravljanje zasebnega varovanja ali je sam varnostni menedžer;

> so povezane osebe varnostno preverjene in nimajo varnostnih zadržkov;

$\Rightarrow \quad$ osebe iz prejšnje točke niso ali niso bile povezane osebe $\mathrm{v}$ pravni osebi, ki ji je bila odvzeta licenca, in ukrep prepovedi ponovne pridobitve licence še traja;

> zoper prosilca ni uveden postopek za odvzem katere koli druge licence po tem zakonu;

> zoper prosilca $\mathrm{v}$ obdobju zadnjih dveh let ni bil izrečen ukrep začasnega ali pogojnega odvzema licence ali odvzema licence in ukrep prepovedi ponovne pridobitve licence še traja;

> ima v delovnem razmerju varnostno osebje, strokovno usposobljeno glede na obliko varovanja, ki jo želi opravljati;

$>\quad$ ima lasten ali s pogodbo zagotovljen VNC;

> je zavarovan za odgovornost za škodo, ki bi lahko nastala pri njegovem delu;

> ima interni akt, s katerim je določil oznake, delovno obleko, opremo in vozila ter je lastnik ali najemnik poslovnih prostorov v Republiki Sloveniji (»Zzasv-1«, 2011). 
Naloge zasebnega varovanja $\mathrm{v}$ zasebnovarnostnih podjetjih opravlja zasebnovarnostno osebje (varnostnik, varnostni tehnik, operater varnostno-nadzornega centra, pooblaščeni inženir varnostnih sistemov in varnostni menedžer). Najštevilčnejši so varnostniki. To so osebe, ki na podlagi pogodbe o zaposlitvi neposredno izvajajo ukrepe in naloge, določene $\mathrm{v}$ Zzasv-1 ter $\mathrm{v}$ pogodbi med naročnikom in zasebnovarnostnim podjetjem. Gre za reguliran in s tem zaščiten poklic, ki ga lahko opravlja samo oseba, ki:

$\rightarrow \quad$ je dopolnila 18 let;

$>\quad$ ima državljanstvo države članice Evropske unije, Evropskega gospodarskega prostora ali Švicarske konfederacije;

$>\quad$ je ustrezno usposobljena glede na delo, ki ga bo izvajala;

$>\quad$ je varnostno preverjena in zoper njo ne obstajajo varnostni zadržki;

> ji v zadnjih dveh letih ni bila odvzeta službena izkaznica zaradi kršitev določb iz Zzasv-1;

> mora biti psihično in zdravstveno sposobna glede za delo, ki ga bo opravljala, ter

\ aktivno obvlada slovenski jezik (»Zzasv-1«, 2011).

Varnostnik sme pri svojem delu uporabiti naslednje ukrepe:

- Opozorilo: Varnostnik sme opozoriti osebo na okoliščine in ravnanje, ki pomeni ali bi pomenilo kršitev reda ali javnega reda na varovanem območju (»Zzasv-1«, 2011).

> Ustna odredba: Varnostnik sme osebi, ki s svojim ravnanjem krši red ali javni red na varovanem območju, ogroža premoženje, osebno varnost ali življenje ljudi, izreči ustno navodilo ali zahtevo, da s kršitvijo ali ogrožanjem takoj preneha ali da zapusti varovano območje (»Zzasv-1«, 2011).

> Ugotavljanje istovetnosti: Varnostnik sme ugotoviti istovetnost osebe na varovanem območju, kadar je to potrebno za varnost ljudi in premoženja ali oseb, ki jih varuje, ali če tako določa red na varovanem območju (»Zzasv-1«, 2011).

> Površinski pregled: Varnostnik sme površinsko pregledati vrhnja oblačila, notranjost vozila, tovor in prtljago osebe na varovanem območju, če je to potrebno za varnost ljudi ter premoženja ali za varnost osebe, ki jo varuje, ali če tako določa red na varovanem območju (»Zzasv-1«, 2011). 
Preprečitev vstopa na varovano območje: Varnostnik sme osebi preprečiti vstop na varovano območje:

- $\quad$ če ne soglaša s površinskim pregledom;

- $\quad$ če pri površinskem pregledu najde predmete iz 4. odstavka 49. člena tega zakona;

- če nasprotuje ugotavljanju njene istovetnosti ali istovetnosti ni mogoče ugotoviti;

- $\quad$ če ne upošteva reda na varovanem območju ali javnega reda ali

- $\quad$ če je to potrebno zaradi preprečitve neposrednega ogrožanja ljudi in premoženja na varovanem območju (»Zzasv-1«, 2011).

- Zadržanje osebe: Varnostnik sme zadržati osebo do prihoda policije, vendar največ dve uri:

- $\quad$ če je bila zalotena v okoliščinah, ki kažejo na storitev kaznivega dejanja, za katero se storilec preganja po uradni dolžnosti;

- $\quad$ če je bila zalotena pri kršitvi reda ali javnega reda na varovanem območju in ne ravna v skladu $\mathrm{z}$ ukrepi varnostnika ali s silo ali grožnjo, da bo neposredno uporabila silo, ovira ali preprečuje izvedbo ukrepa varnostniku ali

- $\quad$ če oseba na varovanem območju ali pri izstopu z varovanega območja odkloni preverjanje istovetnosti ali te ni mogoče ugotoviti ali ne soglaša s površinskim pregledom vrhnjih oblačil, notranjosti vozila, tovora in prtljage (»ZZasv-1«, 2011).

- Uporaba fizične sile: Varnostnik sme uporabiti fizično silo, če drugače ne more:

- $\quad$ preprečiti osebi neupravičen vstop na varovano območje;

- $\quad$ odstraniti osebe $z$ varovanega območja, če se tam neupravičeno zadržuje;

- $\quad$ preprečiti neposrednega ogrožanja ljudi ali premoženja;

- odvrniti istočasnega protipravnega napada na sebe ali osebo, ki jo varuje, ali

- $\quad$ zadržati osebe do prihoda policije (»Zzasv-1«, 2011).

> Uporaba sredstev za vklepanje ali vezanje: Varnostnik sme uporabiti sredstva za vklepanje ali vezanje, če s fizično silo ne more preprečiti neposrednega ogrožanja ljudi ali premoženja, odvrniti istočasnega pro- 
tipravnega napada na sebe ali osebo, ki jo varuje, ali če drugače ne more zadržati osebe do prihoda policije (»Zzasv-1«, 2011).

Varnostnik lahko pri svojem delu uporablja tudi druga sredstva, in sicer plinski razpršilec, službenega psa, orožje (»Zzasv-1«, 2011).

Pravilnik o izvajanju Zakona o zasebnem varovanju še podrobneje določa:

> pogoje za opravljanje zasebnega varovanja;

$\checkmark$ vsebino vloge za pridobitev licence;

$\rightarrow$ obliko, ceno in vsebino certifikata o licenci;

$>$ vsebino vloge za varnostno preverjanje;

> vsebino vloge za pridobitev službene izkaznice;

> obliko, ceno in vsebino službenih izkaznic;

> vsebino vloge za pridobitev soglasja za opravljanje dejavnosti zasebnega varovanja tujim osebam;

> obliko in vsebino certifikata o soglasju za opravljanje dejavnosti zasebnega varovanja tujim osebam;

> vsebino vloge za registracijo opravljanja internega varovanja;

> podrobnejši način izvajanja ukrepov in drugih sredstev varnostnika;

$>$ način in vsebino izvajanja strokovnega nadzora reprezentativnega združenja ter pristojnosti in sestavo neodvisnih komisij (Pravilnik o izvajanju Zakona o zasebnem varovanju, 2011).

Zakonski in podzakonski predpisi pa niso edini, ki urejajo delovanje zasebnega varovanja. Zasebnovarnostno podjetje je namreč s kodeksom o etiki (Zbornica za razvoj zasebnega varovanja, 2012) zavezano, da bo naloge opravljalo pravično in vljudno. Imetniki licenc so obvezani k spoštovanju človekovih pravic in temeljnih svoboščin ter k moralni odgovornosti svojih ravnanj. Kodeks obvezuje imetnike licenc k strokovnem delovanju, vzpodbuja zdravo konkurenco $\mathrm{z}$ namenom učinkovitega delovanja zasebnovarnostnih podjetij in prinaša sodelovanje imetnikov licenc na področju usposabljanja in izobraževanja varnostnikov (Dvojmoč in Sotlar, 2018). 
Zasebno varovanje je mogoče razumeti tudi v smislu zagotavljanja nadstandardne varnosti, ki si jo privoščijo posamezniki, podjetja in ustanove, ki potrebujejo dodatno varovanje in ne zgolj tisto, ki ga zagotavljajo državne službe. Poleg tega pa Uredba o obveznem organiziranju varovanja (ustrezno zapisati vir) določa, katera podjetja, državni organi, ustanove in posamezniki (zavezanci) morajo zaradi narave svojega delovanja obvezno organizirati tovrstno varovanje. Obvezno varovanje pa tudi konkretne varnostne ukrepe morajo zavezanci zagotoviti, če:

> porabljajo ali hranijo radioaktivne snovi, jedrska goriva, odpadke in druge ljudem ter okolju nevarne snovi ter naprave;

> upravljajo zmogljivosti, sisteme ali njihove dele, ki so bistveni za vzdrževanje ključnih družbenih funkcij, zdravja, varnosti, zaščite, gospodarske in družbene blaginje ljudi ter katerih okvara ali uničenje bi imela resne posledice na nacionalno varnost Republike Slovenije zaradi nezmožnosti vzdrževanja teh funkcij (promet, energija, telekomunikacije);

> hranijo arhivsko gradivo in predmete, ki predstavljajo kulturno dediščino;

> upravljajo javna letališča ali morska pristanišča za mednarodni javni promet ali izvajajo prevoze $\mathrm{v}$ mednarodnem letalskem in morskem prometu ali

$>\quad$ je iz posebnih varnostnih razlogov nujno potrebno (»Zzasv-1«, 2011). 


\section{Javno naročanje v Sloveniji}

Javno naročanje je v Republiki Sloveniji definirano v različnih zakonih. Potrebno je upoštevati naslednje zakone, pravilnike in predpise:

> Zakon o javnem naročanju [ZJN-3],

$\rightarrow$ Zakon o delovnih razmerjih [ZDR-1],

$>$ Zakon o zasebnem varovanju [Zzasv-1],

$>$ Zakon o minimalni plači [ZMinP],

$>$ Kolektivno pogodbo dejavnosti zasebnega varovanja. 
V Sloveniji za vodilo javnega naročanja uporabljamo Zakon o javnem naročanju (v nadaljevanju ZjN-3), ki zavzema tudi varnostni del, in sicer v 26. členu z naslovom »Mešana javna naročila, ki zajemajo več dejavnosti in vključujejo obrambne ali varnostne vidike«. Ta člen se uporablja v primeru mešanih javnih naročil, katerih predmet je javno naročilo, ki je zajeto $\mathrm{v}$ zakonu in ki ureja javno naročanje na področju obrambe ter varnosti.

Poznamo sedem postopkov javnega naročanja. Lahko gre za oddajo naročila po odprtem postopku, oddajo naročila po postopku s predhodnim ugotavljanjem sposobnosti, konkurenčni dialog, oddajo javnega naročila po postopku s pogajanji po predhodni objavi, oddajo javnega naročila po postopku s pogajanji brez predhodne objave, postopek oddaje naročila male vrednosti in predrevizijski postopek/revizijski postopek. Za nas je najbolj pomemben odprti postopek, saj se tudi najpogosteje uporablja $\mathrm{v}$ praksi naročanja zasebnovarnostnih storitev. Opredelili bomo celoten postopek javnega naročanja. $\mathrm{Na}$ začetku odprtega postopka se izračuna ocenjene vrednosti. Opredelitev izračuna ocenjene vrednosti je zapisana v 14. členu ZJN-3. Ta izračun opravi strokovna komisija, ki je opredeljena v 68. členu ZJN-3. Sledi sklep o začetku postopka, ki je opredeljen v 14., 70., 94. členu ZJN-3. Poda se razpisna dokumentacija, ki se objavi k obvestilu o javnem naročilu. To je opredeljeno od 57. - 59. člena ZJN-3 in v 71. in 72. členu ZJN-3. Dodajo se spremembe, dopolnitve in pojasnila razpisne dokumentacije, ki so opredeljene v 81. členu ZjN-3. Potem pa se postopek loči glede na potrebno spremembo javnega naročila, če je potrebna ali ni potrebna. Če je sprememba objave javnega naročila potrebna, se postopek nadaljuje z objavo spremembe razpisne dokumentacije in se objavi obvestilo o dodatnih informacijah, informacijah o nedokončanem postopku ali popravku. Če spremembe objave javnega naročila niso potrebne, potem se postopek nadaljuje $\mathrm{z}$ odpiranjem ponudb, zraven pa se vodi zapisnik odpiranja ponudb $\mathrm{v}$ treh delovnih dnevih in vrača se prepozno prejete ponudbe. Naročnik mora na portalu javnih naročil objaviti obvestila $\mathrm{v}$ zvezi $\mathrm{z}$ javnim naročilom, katerega vrednost je enaka ali višja od vrednosti, navedene $\mathrm{v}$ samem zakonu. V ZJN-3 (75. in 76. člen) so določeni tudi razlogi za izključitev iz postopka in pravila ter pogoji za sodelovanje. Med druge obvezne sestavine zakon vključuje opredelitev same vsebine in obseg predmeta javnega naročila. Po odpiranju ponudb sledi preveritev ponudbe, ki je opredeljena v 41. in 77. členu ZJN-3. Kasneje so še dopustne dopolnitve ponudbe, ki so opredeljene v 78. členu ZJN-3. Po dopustnih dopolnitvah sledi predlog strokovne komisije, ki odloči o oddaji naročila, ki je opredeljena v 79. členu ZJN-3. Odločitev o oddaji naročila je lahko izločitev ponudb, ustavitev postopka, zavrnitev vseh ponudb, odstop od izvedbe javnega naročila. Te odločitve so opredeljene $v 80$. členu ZjN-3. Po odločitvi sledijo zahteve za vpogled $\mathrm{v}$ ponudbe, zahteva za dodatno obrazložitev odločitve in zahteva za revizijo postopka. Vpogled v ponudbein dodatna 
obrazložitev odločitve sta opredeljena $\mathrm{v}$ 22. členu in 79. členu ZJN-3. Če je zahteva za revizijo postopka potrjena, se postopek nadaljuje in zaključi v skladu z ZPVPJN. Če revizijski postopek ni potreben, se postopek nadaljuje s pravnomočno odločitvijo o oddaji naročila in se naredi objava obvestila o oddaji naročila v skladu z 58., 59. in 62. členom ZJN-3. Sledi končno poročilo o oddaji naročila, ki je opredeljeno v 105. členu ZJN-3.

Sama narava naročila mora biti napisana na podlagi danih meril, ki zagotovijo skladnost $\mathrm{z}$ načeli. Merila za oddajo javnega naročila morajo biti napisana nediskriminatorno, sorazmerno, povezana morajo biti $\mathrm{z}$ naravo naročila. $\mathrm{V}$ prvem odstavku 84. člena ZjN-3 je določeno, da naročnik odda javno naročilo na podlagi ekonomsko najugodnejše ponudbe. Drugi odstavek 84. člena ZjN-3 določa, da se ekonomsko najugodnejša ponudba določi na podlagi cene ali stroškov ob uporabi pristopa stroškovne učinkovitosti. Zajemala naj bi najboljše razmerje med kakovostjo in ceno ter okoljske ali socialne vidike. Eden izmed pomembnejših pokazateljev, da ponudba ni verodostojna, je neobičajno nizka cena ponudbe. Pri takšnem pojavu zakon navaja tri stanja, za katera mora naročnik preveriti ozadje. Pri tem ne prepoveduje preverbe tudi v drugačnih pogojih. Ključno pri javnih naročilih je, da se upoštevajo roki za prejem ponudb in prijav, ki jih navaja sam zakon. Minimalni rok za prejem ponudb je 35 dni. Po izteku roka za prejem ponudb naročnik ne sme spreminjati ali dopolnjevati le-te (»Zakon o javnem naročanju [ZJN-3]«, 2015).
Merila za naročanje storitev zasebnega varovanja so opredeljena $v 84$. členu ZJN-3, ki opredeljuje, da »naročnik odda javno naročilo na podlagi ekonomsko najugodnejše ponudbe« (»Zakon o javnem naročanju [ZjN-3A] «, 2018). V tem členu zakona so opredeljena tudi sama merila za oddajo javnega naročila.

Usmeritve v zvezi z javnim naročanjem se nahajajo v dokumentu Smernice za javno naročanje storitev zasebnega varovanja, ki ga je sprejelo Ministrstvo za javno upravo Republike Slovenije. Poleg opredelitve storitve zasebnega varovanja sta $\mathrm{v}$ smernicah predstavljena izračun ocenjene vrednosti in izbira postopka javnega naročanja. Menimo, da so smernice pomanjkljivo zapisane, saj smo ugotovili kar nekaj pomanjkljivosti, ki jih je potrebno dopolniti. Naše pripombe glede smernic so, da bi morale biti napisane na bolj praktičen način in vsebovati postopke javnega naročanja, ki so prilagojeni našemu trgu. Smernice za naročanje storitev zasebnega varovanja bi morale biti ločene glede na sektorje naročanja, ki so vidni iz prakse. Gre za ločevanje smernic naročanja na segmente trgovine, javne uprave, industrije, fizičnih oseb/hiš in finančnega sektorja. Cene se razlikujejo glede na usposobljenost zaposlenih, delovne pogoje in zahtevnost nalog. Naročniku je svetovano tudi glede primernega časa za izvajanje javnih naročil in določanja rokov za prejem ponudb in prijav. V Smernicah za naročanje storitev zasebnega varovanja se nam zdi ključnega pomena to, da je predstavljen opis pogojev usposobljenosti gospodarskih subjektov. Pomembno je tudi, 
da so predstavljeni pogoji za sodelovanje in razlogi za izključitev. Pogoji se osredotočajo na ustreznost za opravljanje poklicne dejavnosti, finančne pogoje, tehnično in strokovno usposobljenost. Ključnega pomena se nam zdi tudi, da si lahko naročnik pogleda tudi, kako je z izločitvijo ponudbe pri neobičajno nizki ceni in merila za oddajo javnih naročil, ki so podrobneje opisana tudi v prilogi. Prav tako so v prilogi podrobno opisani pogoji za sodelovanje (Ministrstvo za javno upravo, 2019).

Zasebno varovanje v Sloveniji je urejeno z Zakonom o zasebnem varovanju. Naročniki storitev zasebnega varovanja morajo zahtevati, da so izpolnjeni vsi zakonski pogoji, vključno z licencami in ostalimi pogoji, ki jih Zzasv-1 določa v svojih določbah, ob tem pa bi moral biti naročnik proaktiven ter navesti tudi dodatne kriterije in merila, za katere želi, da jih ponudba vsebuje ter po katerih bo ocenjeval prejete ponudbe. Podjetje, ki se prijavlja na razpis, mora imeti registrirano dejavnost zasebnega varovanja. Povedano drugače, Zzasv-1 v 3. členu navaja, da lahko zasebno varovanje opravlja, ga ponuja ali o njem svetuje v okviru svoje usposobljenosti kot pridobitno dejavnost za naročnike na podlagi pogodbenega odnosa, gospodarska družba ali samostojni podjetnik posameznik, ki ima registrirano dejavnost (Zzasv-1, 2011). Nadalje pa tretje poglavje Zzasv-1 konkretneje opredeljuje opravljanje zasebnega varovanja, kjer so med drugim relevantne tudi določbe o opravljanju zasebnega varovanja zgolj $\mathrm{z}$ varnostnim osebjem, ki izpolnjuje zakonske pogoje in s katerim ima imetnik licence sklenjeno delovno razmerje. »Imetniki licenc in varnostno osebje morajo ves čas opravljanja dejavnosti izpolnjevati pogoje za opravljanje zasebnega varovanja in opravljati zasebno varovanje $\mathrm{v}$ skladu s tem zakonom ter predpisi, izdanimi na njegovi podlagi, glede na obliko varovanja, ki jo opravljajo, « nadalje veleva 6. odstavek 11. člena, sem pa sodi tudi ustrezno usposabljanje in izpopolnjevanje varnostnega osebja. Potrebno je tudi ustrezno izkazovanje, zagotovljen mora biti lasten ali pogodbeni notranji nadzor nad opravljanjem nalog varnostnega osebja $\mathrm{z}$ varnostniki nadzorniki in varnostnimi menedžerji, kot izhaja iz 12. člena o notranjem nadzoru. Zasebno varovanje se mora opravljati v skladu s sprejetimi in objavljenimi slovenskimi nacionalnimi standardi, izhajajoč iz 13. člena, relevantno pa je tudi ustrezno izpolnjevanje določb o varovanju podatkov ter poslovnih skrivnosti (14. člen), zavarovanju odgovornosti za škodo in zavarovanju odgovornosti (15. člen), izpolnjevanje zahtev v zvezi z varnostnimi zadržki (16. člen) ter varnostnim preverjanjem (17. člen). Nadalje lahko oviro predstavljajo tudi sklenjene pogodbe o opravljanju dejavnosti ali nalog, ki niso združljive $\mathrm{z}$ zasebnim varovanjem (18. člen).

Merila za naročanje storitev zasebnega varovanja so ključnega pomena in so zapisana v Zakonu o javnem naročanju. Merila so bolj praktično opredeljena v Priročniku o nakupu kakovostnih storitev zasebnega varovanja, ki ga je objavilo Ministrstvo za notranje zadeve, in v vseh javnih razpisih, ki se navezujejo na naročanje storitev 
zasebnega varovanja. Javni razpisi so dokumenti, ki prikazujejo najbolj praktičen pristop in odražajo realno stanje. Če želimo zasnovati priročnik, ki bo za bralca, ki naroča storitve zasebnega varovanja razumljiv, potem se moramo posvetiti javnim razpisom, katerih bistvo je zasebno varovanje. Pomembno je pogledati, kako ti javni razpisi opredeljujejo merila za naročanje storitev zasebnega varovanja in kakšne so specifike glede naročnikov, ki potrebujejo različne vrste storitev zasebnega varovanja. Pri zasebnem varovanju poznamo specifike naročanja fizičnega ali tehničnega varovanja. Glede javnega naročanja storitev zasebnega varovanja pa lahko javne razpise razdelimo $\mathrm{v}$ pet sklopov naročnikov. Lahko gre za naročnike, ki potrebujejo zasebnovarnostne storitve na področju varovanja trgovine, fizičnih oseb/hiš, v javni upravi, industriji in v finančnem sektorju. Kljub temu moramo vedeti, da se elementi med seboj prepletajo. V priročniku o nakupu storitev zasebnega varovanja je opredeljen tristopenjski model postopka oddaje javnih naročil, in sicer merila izključitve, razlogi za sodelovanje ter merila za oddajo naročila. V 5. poglavju so opredeljena merila kakovosti za nakup storitev zasebnega varovanja. Ta merila so pregled ozadja zasebnovarnostne osebe, spretnosti in zmožnosti varnostnikov, izkušnje, pogoji zaposlitve, oprema, tehnična podpora, kontrola kakovosti, izkušnje ter dosežki podjetja, etika in kodeks ravnanja podjetja, mala in srednje velika podjetja (CoEss, n. d.). Pričujoč priročnik se od omenjenega razlikuje po tem, da gre v prvem delu za pregled literature s strani študentov varstvoslovja, kar dopolnjujemo $\mathrm{z}$ doprinosom delovnih mentorjev iz gospodarske sfere, konkretno njihovih opažanj in ugotovitev $\mathrm{z}$ dela $\mathrm{v}$ praksi. 


\section{Analiza prakse javnega naročanja na področju zasebnega varovanja}

Da bi bralcu na razumljiv način predstavili naročanje storitev zasebnega varovanja, smo zbrali in pregledali štiri javna naročila na področju zasebnega varovanja. Poiskali smo njihove skupne točke in določili najpomembnejše razlike. $V$ enem izmed javnih naročil (Javno naročilo 1) je tako zapisan predmet javnega naročila, ki je izvajanje zasebnega varovanja in zajema opravljanje FiT-varovanja (vlom in požarno varovanje), fizično varovanje, varnostne obhode, prevoz denarja ter vzdrževanje alarmno varnostne tehnike. Oblike in obseg zasebnega varovanja so opredeljene $\mathrm{v}$ tehničnem opisu predmeta naročila. Okvirni sporazum za izvajanje zasebnega varovanja je sklenjen za obdobje 24 mesecev. Vsaka tematika opravljanja zasebnega varovanja je $\mathrm{v}$ razpisu podrobno opisana. $\mathrm{V}$ javno naročilo je dodana zakonodaja iz ZJN-3. $\mathrm{Na}$ koncu naročila so opredeljeni vsebina ponudbene dokumentacije in podatki o podizvajalcu. Vsebina ponudbene dokumentacije zajema obrazec za kuverto, ponudbo, ponudbeni predračun, podatke o ponudniku, izjavo o ugotavljanju sposobnosti ponudnika, izjavo članov organov in zastopnikov gospodarskega subjekta ter pooblastilo za pridobitev podatkov iz kazenske evidence, izjavo o udeležbi fizičnih in pravnih oseb v lastništvu ponudnika, izjavo o ugotavljanju sposobnosti podizvajalca. Podatki o udeležbi podizvajalca zajemajo izjavo o neposrednem izplačilu, izjavo o sodelovanju s podizvajalci, seznam referenc, potrditev referenc s strani posameznih naročnikov, osnutek okvirnega sporazuma, zavarovanje dobre izvedbe obveznosti iz okvirnega sporazuma, certifikat za licence, zavarovalno polico, pooblastilo za zaščito in požarno varovanje ter obrazec pooblastila za sodelovanje na javnem odpiranju ponudb (Komunala Kranj, 2016). Vsebina dokumentacije je pri vseh petih javnih naročilih za zasebno varovanje enaka. V naslednjih treh izbranih javnih naročilih prikazujemo posebnosti oziroma razlike. $V$ javnem naročilu 2 je posebnost ta, da se bolj striktno osredotoča na zakonodajo. Naročnik od ponudnika zahteva potrdilo, da v zadnjih šestih mesecih ni imel neporavnanih obveznosti, in predložitev ustreznih BON-obrazcev. Referenca, ki jo zahteva naročnik, je usposobljenost ponudnika, torej, da je v obdobju zadnjih dveh let pred rokom za prejem ponudb zagotavljal storitve receptorsko-varnostne službe in fizično-tehničnega protipožarnega varovanja vsaj trem različnim naročnikom $\mathrm{v}$ vrednosti najmanj 50.000 EUR brez DDV. Naročnik zahteva tudi tehnično sposobnost varnostnega osebja $\mathrm{z}$ ustrezno licenco in opredeljuje natančne tehnične specifikacije za storitve receptorsko-varnostne službe in fizično-tehnično varovanje (Kemijski inštitut, 2014). $\mathrm{V}$ javnem naročilu 3 se zahteva tehnično in strokovno sposobnost. Naročnik bo priznal usposobljenost ponudniku, ki bo imel naslednje reference: $\mathrm{v}$ zadnjih treh letih pred objavo javnega naročila je ponudnik opravljal storitve fizičnega varovanja premoženja in sprejema signalov ter intervencije za najmanj dva naročnika. Vse našteto pa je potekalo vsaj eno leto neprekinjeno. Vrednost posamezne reference mora biti najmanj 130.000 EUR brez DDv letno ali da 
je vgradil sisteme tehničnega varovanja pri najmanj dveh naročnikih, ki ga ima naročnik v najemu že vsaj eno leto neprekinjeno. Pogodbena vrednost posameznega najema mora biti najmanj 20.000 EUR brez DDV (Mestna občina Maribor, 2018). Javno naročilo 4 je zastavljeno podobno kot že predhodno omenjeno javno naročilo 2. Razlika je v tem, da to javno naročilo vsebuje obrazec za ugotavljanje pravilnosti ponudbe (obrazec sestoji iz 24 trditev, na katere se odgovarja z "da" ali "ne") (Ministrstvo za gospodarski razvoj in tehnologijo, 2006).

V Tabeli 3 so prikazane posebnosti, ki smo jih zaznali v predhodno predstavljenih javnih naročilih.

\begin{tabular}{|c|c|c|c|}
\hline & $\begin{array}{c}\text { Kemijski Inštitut } \\
\text { Ljubljana } \\
\text { JAVNO NAROČILO } 2\end{array}$ & $\begin{array}{c}\text { Mestna občina } \\
\text { Maribor } \\
\text { JAVNO NAROČILO } 3\end{array}$ & $\begin{array}{c}\text { Ministrstvo za gospodarski } \\
\text { razvoj in tehnologijo } \\
\text { JAVNO NAROČILO } 4\end{array}$ \\
\hline OSREDOTOČANJE NA ZAKONODAJO & $\mathrm{x}$ & & \\
\hline OSREDOTOČANJE NA REFERENCE & $\mathrm{x}$ & $\mathrm{x}$ & \\
\hline TEHNIČNA IN STROKOVNA USPOSOBLJENOST & & $\mathrm{x}$ & \\
\hline OBRAZEC ZA UGOTAVLJANJE PRAVILNOSTI PONUDBE & & & $\mathrm{x}$ \\
\hline
\end{tabular}

Tabela 3: Posebnosti predhodno predstavljenih javnih naročil 



\section{Pregled kriterijev za izbor izvajalca storitev zasebnega varovanja}

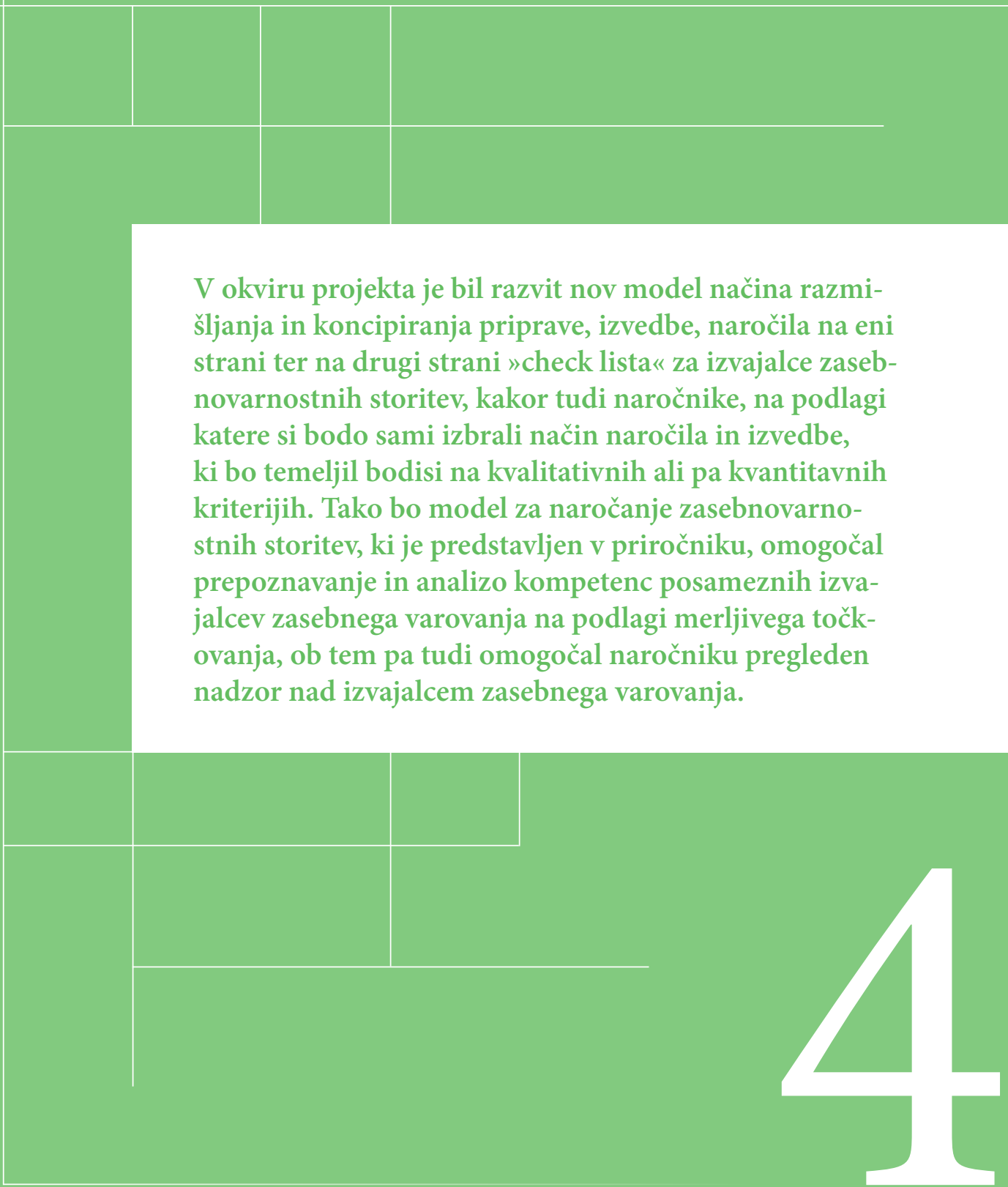


Namen priročnika je izobraževanje pred- ki se zahtevajo in jih mora izpolnjevati varvsem naročnikov zasebnovarnostnih storitev in tudi izvajalcev, ki lahko ugotovitve ter model iz priročnika uporabijo za strateško prednost. $V$ pomoč bo širši množici uporabnikov, saj ne smemo zanemariti dejstva, da $\mathrm{v}$ panogi zasebnega varovanja trenutno deluje preko 6.500 oseb s posebnimi pooblastili in pravicami za poseg $\mathrm{v}$ človekove pravice ter svoboščine. Če to povežemo še s spremenljivi oblikami ogrožanja, se pomen jasno zastavljenih ciljev in kriterijev za učinkovito in na organizacijo prilagojeno naročanje zasebnovarnostnih storitev še poveča.

$\mathrm{Z}$ izvajanjem aktivnosti in uporabo modela za naročanje zasebnovarnostnih storitev, ki je bil razvit med PKP-projektom, so študentje pridobili kompetence za analiziranje ter ocenjevanje varnostnih tveganj, tveganj pri naročanju zasebnovarnostnih storitev in obdelavo podatkov, pomembnih za odločanje o naročanju zasebnovarnostnih storitev, kar smo s priročnikom ter vzpostavitvijo spletne stani predstavili tudi uporabnikom zasebnovarnostnih storitev in njenim izvajalcem ter s pričujočimi kriteriji zaokrožili vsebino priročnika.

Zahteve služijo tudi kot nabor kriterijev za izbor storitev zasebnega varovanja, pri čemer je smiselno ločevati med pogoji, ki se zahtevajo in jih mora izpolnjevati zasebnovarnostna družba, in pogoji, nostno osebje. Na tej podlagi so $v$ nadaljevanju predstavljeni kriteriji izbora izvajalca storitev zasebnega varovanja oz. naročanja storitev v petih sektorjih - trgovina, javna uprava, industrija, fizične osebe/hiše in $v$ finančnem sektorju.

Pri vsakem sektorju je delitev na fizično in tehnično varovanje. $Z$ oznako $\mathrm{x}$ smo izbrali le tiste kriterije, ki se nam zdijo najpomembnejši in katere je priporočljivo obvezno vključiti v načrt naročanja zasebnovarnostnih storitev v organizaciji. Vsi ostali kriteriji, ki niso označeni $\mathrm{z}$ oznako $\mathrm{x}$, so dodatni, s katerimi lahko naročnik zasebnovarnostnih storitev podrobneje opredeli, kakšno storitev ponudnika zasebnovarnostnih storitev želi. Ob tem se je potrebno zavedati, da so potrebe $\mathrm{v}$ različnih sektorjih različne in je nabor izbornih kriterijev zato večji.

Obravnavamo štiri osnovne sklope. V 1. sklopu so v Tabeli 4 omenjene licence, ki jih lahko pridobi zasebnovarnostno podjetje, v 2. sklopu so v Tabeli 5 obravnavani kriteriji veščin in znanj v sklopu kompetenc varnostnega osebja, ki izvaja naloge zasebnega varovanja, 3. sklop vsebuje pregled kriterijev, ki se nanašajo na organizacijsko, finančno in kadrovsko zmogljivost, kot prikazuje Tabela 6 , in 4 . sklop, kjer so v Tabeli 7 prikazani kriteriji, ki jih družba ocenjuje kot pomembne pri zagotavljanju storitev zasebnega varovanja. 


\begin{tabular}{|c|c|c|c|c|c|c|c|c|c|c|c|}
\hline \multicolumn{2}{|c|}{ IZBOR KRITERIJEV } & F & $\mathrm{T}$ & F & $\mathrm{T}$ & F & $\mathrm{T}$ & F & $\mathrm{T}$ & F & $\mathrm{T}$ \\
\hline 1 & LICENCE & & & & & & & & & & \\
\hline 1 & VAROVANJE LJUDI IN PREMOŽENJA (FIZIČNO VAROVANJE ${ }^{\star}$ ) & $\mathrm{x}$ & & $\mathrm{x}$ & & $\mathrm{x}$ & & $\mathrm{x}$ & & $\mathrm{x}$ & \\
\hline & OBHODNO VAROVANJE ${ }^{*}$ & $\mathrm{x}$ & & $\mathrm{x}$ & & $\mathrm{x}$ & & $\mathrm{x}$ & & $\mathrm{x}$ & \\
\hline 2 & VAROVANJE OSEB & & & & & $\mathrm{x}$ & & $\mathrm{x}$ & & $\mathrm{x}$ & \\
\hline 5 & NAČRTOVANJE SISTEMOV TEHNIČNEGA VAROVANJA & & $\mathrm{x}$ & & $\mathrm{x}$ & & $\mathrm{x}$ & & $\mathrm{x}$ & & $\mathrm{x}$ \\
\hline 6 & IZVAJANJE SISTEMOV TEHNIČNEGA VAROVANJA & & $\mathrm{x}$ & & $\mathrm{x}$ & & $\mathrm{x}$ & & $\mathrm{x}$ & & $\mathrm{x}$ \\
\hline 7 & PREVOZ IN VAROVANJE GOTOVINE TER DRUGIH VREDNOSTNIH POŠILJK & $\mathrm{x}$ & $\mathrm{x}$ & $\mathrm{x}$ & $\mathrm{x}$ & & & $\mathrm{x}$ & $\mathrm{x}$ & & \\
\hline 8 & UPRAVLJANJE Z VARNOSTNO-NADZORNIM CENTROM (VNC) & $\mathrm{x}$ & $\mathrm{x}$ & $\mathrm{x}$ & $\mathrm{x}$ & $\mathrm{x}$ & $\mathrm{x}$ & $\mathrm{x}$ & $\mathrm{x}$ & $\mathrm{x}$ & $\mathrm{x}$ \\
\hline 2 & VARNOSTNO OSEBJE & & & & & & & & & & \\
\hline 1 & VARNOSTNIK & $\mathrm{x}$ & & $\mathrm{x}$ & & $\mathrm{x}$ & & $\mathrm{x}$ & & $\mathrm{x}$ & \\
\hline 5 & POOBLAŠČENI INŽENIR VARNOSTNIH SISTEMOV & & $\mathrm{x}$ & & $\mathrm{x}$ & & $\mathrm{x}$ & & $\mathrm{x}$ & & $\mathrm{x}$ \\
\hline 6 & VARNOSTNIK INTERVENT ${ }^{*}$ & $\mathrm{x}$ & & $\mathrm{x}$ & & $\mathrm{x}$ & & $\mathrm{x}$ & & $\mathrm{x}$ & \\
\hline 7 & VARNOSTNIK NA VAROVANJU JAVNIH ZBIRANJ* & $\mathrm{x}$ & & $\mathrm{x}$ & & & & & & & \\
\hline 8 & VARNOSTNIK NA VAROVANJU PRIREDITEV V GOSTINSKIH LOKALIH* & $\mathrm{x}$ & & $\mathrm{x}$ & & & & & & & \\
\hline 9 & VARNOSTNIK RENTGENSKI OPERATER ${ }^{*}$ & & & $\mathrm{x}$ & & & & & & & \\
\hline 10 & VARNOSTNIK S PLINSKIM RAZPRŠILCEM ${ }^{*}$ & $\mathrm{x}$ & & $\mathrm{x}$ & & $\mathrm{x}$ & & $\mathrm{x}$ & & $\mathrm{x}$ & \\
\hline 11 & OPERATIVNI GASILEC ${ }^{*}$ & $\mathrm{x}$ & & $\mathrm{x}$ & & $\mathrm{x}$ & & $\mathrm{x}$ & & $\mathrm{x}$ & \\
\hline 12 & VARNOSTNIK PREVOZNIK GOTOVINE ${ }^{*}$ & $\mathrm{x}$ & $\mathrm{x}$ & $\mathrm{x}$ & $\mathrm{x}$ & & & $\mathrm{x}$ & $\mathrm{x}$ & & \\
\hline 13 & VARNOSTNIK NADZORNIK & $\mathrm{x}$ & $\mathrm{x}$ & $\mathrm{x}$ & $\mathrm{x}$ & $\mathrm{x}$ & $\mathrm{x}$ & $\mathrm{x}$ & $\mathrm{x}$ & $\mathrm{x}$ & $\mathrm{x}$ \\
\hline 14 & OPERATER VNC & $\mathrm{x}$ & $\mathrm{x}$ & $\mathrm{x}$ & $\mathrm{x}$ & $\mathrm{x}$ & $\mathrm{x}$ & $\mathrm{x}$ & $\mathrm{x}$ & $\mathrm{x}$ & $\mathrm{x}$ \\
\hline 15 & VARNOSTNI MENEDŽER & $\mathrm{x}$ & $\mathrm{X}$ & $\mathrm{x}$ & $\mathrm{x}$ & $\mathrm{x}$ & $\mathrm{x}$ & $\mathrm{x}$ & $\mathrm{x}$ & $\mathrm{x}$ & $\mathrm{x}$ \\
\hline
\end{tabular}

Tabela 4: Pregled kriterijev, ki se nanašajo na licence in varnostno osebje, ki izvaja varovanje 


\begin{tabular}{|c|c|c|}
\hline \multicolumn{3}{|c|}{ KOMPETENCE VARNOSTNEGA OSEBJA } \\
\hline 1 & DELOVNE IZKUŠNJE & \\
\hline 2 & FIZIČNA PRIPRAVLJENOST & \\
\hline 3 & IZKUŠNJE PRI DELU S STRANKAMI & \\
\hline 4 & KOMUNIKATIVNOST & \\
\hline 5 & MOTIVIRANOST & \\
\hline 6 & NUDENJE PRVE POMOČI & \\
\hline 7 & OBVLADOVANJE KONFLIKTNIH STRANK & \\
\hline 8 & ODZIVNOST & \\
\hline 9 & OPRAVLJEN TEČAJ VARNE VOŽNJE & \\
\hline 10 & POŠTENOST & \\
\hline 11 & POZNAVANJE MEDSEBOJNIH VPLIVOV DEJAVNOSTI VAROVANJA & \\
\hline 12 & POZNAVANJE NAČEL KAKOVOSTI & \\
\hline 13 & POZNAVANJE SPECIFIK PODROČJA DELA & \\
\hline 14 & POZNAVANJE STROKOVNOSTI OPRAVLJANJA DELA & \\
\hline 15 & POZNAVANJE ZAKONITOSTI IZVAJANJA NALOG & \\
\hline 16 & PRAVOČASNOST & \\
\hline 17 & PREPOZNAVANJE NEVARNIH OKOLIŠČIN IN VEDENJA OBISKOVALCEV & \\
\hline 18 & PRIJAZNOST & \\
\hline 19 & PRILAGODLJIVOST & \\
\hline 20 & RAVNANJE Z OROŽJEM & \\
\hline 21 & SAMOOBRAMBNE VEŠČINE & \\
\hline 22 & SPOSOBNOST IZVAJANJA NALOG & \\
\hline 23 & SPOSOBNOST OSEBNEGA ZAZNAVANJA & \\
\hline 24 & UKREPANJE V KRITIČNIH SITUACIJAH & \\
\hline 25 & UPOŠTEVANJE NAVODIL NADREJENEGA & \\
\hline 26 & USPOSOBLJENOST GAŠENJA ZAČETNIH POŽAROV & \\
\hline 27 & USPOSOBLJENOST IZ POKLICNEGA IZOBRAŽEVANJA & \\
\hline 28 & USPOSOBLJENOST PO PROGRAMIH NPK & \\
\hline 29 & ZANESLJIVOST & \\
\hline 30 & ZAUPLJIVOST & \\
\hline 31 & ZNANJE TUJIH JEZIKOV & \\
\hline 32 & ZUNANJA PODOBA - UREJENOST & \\
\hline
\end{tabular}

Tabela 5: Pregled kriterijev, ki se nanašajo na veščine in znanja v sklopu kompetenc varnostnega osebja, ki izvaja varovanje 


\begin{tabular}{|c|c|c|c|c|c|c|c|c|c|c|c|}
\hline \multirow{2}{*}{\multicolumn{2}{|c|}{ IZBOR KRITERIJEV }} & \multicolumn{2}{|c|}{ TRG. } & \multicolumn{2}{|c|}{ JAV. U. } & \multicolumn{2}{|c|}{ IND. } & \multicolumn{2}{|c|}{ FIN. S. } & \multicolumn{2}{|c|}{ F. OS. } \\
\hline & & $\mathbf{F}$ & $\mathrm{T}$ & F & $\mathrm{T}$ & F & $\mathrm{T}$ & F & $\mathrm{T}$ & F & $\mathrm{T}$ \\
\hline 3 & \multicolumn{11}{|l|}{ OCENJEVALNI KRITERIJI DRUŽBE } \\
\hline \multicolumn{12}{|c|}{ ORGANIZACIJSKA ZMOGLJIVOST } \\
\hline 1 & CELOVITOST PONUDBE & $\mathrm{x}$ & $\mathrm{x}$ & & & $\mathrm{x}$ & $\mathrm{x}$ & & & $\mathrm{x}$ & $\mathrm{x}$ \\
\hline 2 & DOSEGLJIVOST & & & & & & & $\mathrm{x}$ & $\mathrm{x}$ & $\mathrm{x}$ & $\mathrm{x}$ \\
\hline 3 & DRUŽBENA ODGOVORNOST & & & $\mathrm{x}$ & $\mathrm{x}$ & $\mathrm{x}$ & $\mathrm{x}$ & $\mathrm{x}$ & $\mathrm{x}$ & $\mathrm{x}$ & $\mathrm{x}$ \\
\hline 4 & JAVNA PODOBA DRUŽBE & $\mathrm{x}$ & $\mathrm{x}$ & & & & & $\mathrm{x}$ & $\mathrm{x}$ & $\mathrm{x}$ & $\mathrm{x}$ \\
\hline 5 & MERJENJE ZADOVOLJSTVA NAROČNIKOV & $\mathrm{x}$ & $\mathrm{x}$ & & & $\mathrm{x}$ & $\mathrm{x}$ & $\mathrm{x}$ & $\mathrm{x}$ & $\mathrm{x}$ & $\mathrm{x}$ \\
\hline 6 & OBVLADOVANJE TVEGANI - ISO 31001 & & & $\mathrm{x}$ & $\mathrm{x}$ & $\mathrm{x}$ & $\mathrm{x}$ & $\mathrm{x}$ & $\mathrm{x}$ & & \\
\hline 7 & OCENJEVANJE DOBAVITELJEV IN PODIZVAJALCEV & & & & & & & $\mathrm{x}$ & $\mathrm{x}$ & & \\
\hline 8 & ODSOTNOST VARNOSTNIH ZADRŽKOV & & & & & & & $\mathrm{x}$ & $\mathrm{x}$ & & \\
\hline 9 & odzivnost & $\mathrm{x}$ & $\mathrm{x}$ & & & $\mathrm{x}$ & $\mathrm{x}$ & $\mathrm{x}$ & $\mathrm{x}$ & $\mathrm{x}$ & $\mathrm{x}$ \\
\hline 10 & OKOLJSKA ZAVEST - ISO 14001 & $\mathrm{x}$ & & $\mathrm{x}$ & $\mathrm{x}$ & $\mathrm{x}$ & $\mathrm{x}$ & & & $\mathrm{x}$ & $\mathrm{x}$ \\
\hline 11 & POKRITOST OBMOČJA DELOVANJA & $\mathrm{x}$ & $\mathrm{x}$ & & & $\mathrm{x}$ & $\mathrm{x}$ & $\mathrm{x}$ & $\mathrm{x}$ & & \\
\hline 12 & PROCESNO VODENJE & & & & & $\mathrm{x}$ & $\mathrm{x}$ & & & & \\
\hline 13 & REFERENCE & $\mathrm{x}$ & $\mathrm{x}$ & $\mathrm{x}$ & $\mathrm{x}$ & $\mathrm{x}$ & $\mathrm{x}$ & $\mathrm{x}$ & $\mathrm{x}$ & $\mathrm{x}$ & $\mathrm{x}$ \\
\hline 14 & REŠEVANJE REKLAMACIJ & $\mathrm{x}$ & $\mathrm{x}$ & $\mathrm{x}$ & $\mathrm{x}$ & $\mathrm{x}$ & $\mathrm{x}$ & $\mathrm{x}$ & $\mathrm{x}$ & $\mathrm{x}$ & $\mathrm{x}$ \\
\hline 15 & SISTEM VODENJA VARNOSTI IN ZDRAVJA PRI DELU - ISO 45001 & $\mathrm{x}$ & $\mathrm{x}$ & $\mathrm{x}$ & $\mathrm{x}$ & $\mathrm{x}$ & $\mathrm{x}$ & $\mathrm{x}$ & $\mathrm{x}$ & & \\
\hline 16 & SISTEMI UPRAVLJANJA INFORMACIJSKE VARNOSTI - ISO 27001 & & & & & $\mathrm{x}$ & $\mathrm{x}$ & $\mathrm{x}$ & $\mathrm{x}$ & & \\
\hline 17 & SISTEMI VODENJA KAKOVOSTI - ISO 9001 & $\mathrm{x}$ & $\mathrm{x}$ & $\mathrm{x}$ & $\mathrm{x}$ & $\mathrm{x}$ & $\mathrm{x}$ & $\mathrm{x}$ & $\mathrm{x}$ & $\mathrm{x}$ & $\mathrm{x}$ \\
\hline 18 & TRANSPARENTNOST OPRAVLJANJA DEJAVNOSTI & & & $\mathrm{x}$ & $\mathrm{x}$ & $\mathrm{x}$ & $\mathrm{x}$ & $\mathrm{x}$ & $\mathrm{x}$ & & \\
\hline \multicolumn{12}{|c|}{ FINANČNA ZMOGLJIVOST } \\
\hline 1 & ČLANSTVO V REPREZENTATIVNEM ZDRUŽENJU & & & $\mathrm{x}$ & $\mathrm{x}$ & & & $\mathrm{x}$ & $\mathrm{x}$ & & \\
\hline 2 & DODATNO ZAVAROVANJE ODGOVORNOSTI ZA ŠKODO & & $\mathrm{x}$ & $\mathrm{x}$ & $\mathrm{x}$ & $\mathrm{x}$ & $\mathrm{x}$ & $\mathrm{x}$ & $\mathrm{x}$ & $\mathrm{x}$ & $\mathrm{x}$ \\
\hline 3 & DOKAZILO POSLOVNE BANKE O PLAČILNI SPOSOBNOSTI - BON-2 & & & $\mathrm{x}$ & $\mathrm{x}$ & & & $\mathrm{x}$ & $\mathrm{x}$ & & \\
\hline 4 & DOLOČITEV POGODBENE KAZNI & $\mathrm{x}$ & $\mathrm{x}$ & $\mathrm{x}$ & $\mathrm{x}$ & $\mathrm{x}$ & $\mathrm{x}$ & $\mathrm{x}$ & $\mathrm{x}$ & $\mathrm{x}$ & $\mathrm{x}$ \\
\hline 5 & FINANČNA ZAVAROVANJA - BANČNA GARANCIJA & $\mathrm{x}$ & $\mathrm{x}$ & $\mathrm{x}$ & & $\mathrm{x}$ & $\mathrm{x}$ & $\mathrm{x}$ & $\mathrm{x}$ & & \\
\hline 6 & IZPISEK ALI IZKAZ BILANCE & & & $\mathrm{x}$ & $\mathrm{x}$ & & & $\mathrm{x}$ & $\mathrm{x}$ & & \\
\hline 7 & PLAČEVANJE DAVKOV IN PRISPEVKOV ZA SOCIALNO VARNOST & $\mathrm{x}$ & & $\mathrm{x}$ & $\mathrm{x}$ & $\mathrm{x}$ & $\mathrm{x}$ & $\mathrm{x}$ & $\mathrm{x}$ & & \\
\hline 8 & TRANSPARENTNOST POSLOVANJA & & & $\mathrm{x}$ & $\mathrm{x}$ & & & $\mathrm{x}$ & $\mathrm{x}$ & & \\
\hline \multicolumn{12}{|c|}{ KADROVSKA ZMOGLJIVOST } \\
\hline 1 & DELOVNE IZKUŠNJE VARNOSTNEGA OSEBJA IN VODSTVA V DEJAVNOSTI & & $\mathrm{x}$ & & $\mathrm{x}$ & & $\mathrm{x}$ & $\mathrm{x}$ & $\mathrm{x}$ & $\mathrm{x}$ & $\mathrm{x}$ \\
\hline 2 & IZPLAČEVANJE ZAKONSKO DOVOLJENIH NADUR & $\mathrm{x}$ & & $\mathrm{x}$ & & $\mathrm{x}$ & & $\mathrm{x}$ & $\mathrm{x}$ & & \\
\hline 3 & IZPLAČILO ZAKONSKO PREDPISANIH PLAČ & $\mathrm{x}$ & & $\mathrm{x}$ & $\mathrm{x}$ & $\mathrm{x}$ & $\mathrm{x}$ & $\mathrm{x}$ & $\mathrm{x}$ & & \\
\hline
\end{tabular}




\begin{tabular}{|c|c|c|c|c|c|c|c|c|c|c|c|}
\hline \multirow{2}{*}{\multicolumn{2}{|c|}{ IZBOR KRITERIJEV }} & \multicolumn{2}{|c|}{ TRG. } & \multicolumn{2}{|c|}{ JAV. U. } & \multicolumn{2}{|c|}{ IND. } & \multicolumn{2}{|c|}{ FIN. S. } & \multicolumn{2}{|c|}{ F. OS. } \\
\hline & & & & & & & & & & & \\
\hline 3 & \multicolumn{11}{|l|}{ OCENJEVALNI KRITERIJI DRUŽBE } \\
\hline \multicolumn{12}{|c|}{ KADROVSKA ZMOGLJIVOST } \\
\hline 4 & MINIMALNA IZOBRAZBA, STROKOVNA USPOSOBLJENOST OSEBJA IN VODSTVA & & $\mathrm{x}$ & $\mathrm{x}$ & $\mathrm{x}$ & & $\mathrm{x}$ & & & $\mathrm{x}$ & $\mathrm{x}$ \\
\hline 5 & OPRAVLJANJE ZAKONSKO OPRAVLJENIH UR & $\mathrm{x}$ & & & & $\mathrm{x}$ & & $\mathrm{x}$ & $\mathrm{x}$ & & \\
\hline 6 & OSEBNE REFERENCE & & $\mathrm{x}$ & & $\mathrm{x}$ & & $\mathrm{x}$ & & $\mathrm{x}$ & $\mathrm{x}$ & $\mathrm{x}$ \\
\hline 7 & PLAČE IN DRUGI PRIHODKI ZAPOSLENIH & $\mathrm{x}$ & $\mathrm{x}$ & $\mathrm{x}$ & & $\mathrm{x}$ & & $\mathrm{x}$ & $\mathrm{x}$ & $\mathrm{x}$ & \\
\hline 8 & ZAPOSLOVANJE ZA NEDOLOČEN ČAS & $\mathrm{x}$ & & $\mathrm{x}$ & & $\mathrm{x}$ & & $\mathrm{x}$ & $\mathrm{x}$ & & \\
\hline 9 & ZAPOSLOVANJE ZA POLNI DELOVNI ČAS & & & $\mathrm{x}$ & & $\mathrm{x}$ & $\mathrm{x}$ & $\mathrm{x}$ & $\mathrm{x}$ & & \\
\hline
\end{tabular}

Tabela 6: Pregled kriterijev, ki se nanašajo na organizacijsko, finančno in kadrovsko zmogljivost 


\begin{tabular}{|c|c|c|c|c|c|c|c|c|c|c|c|}
\hline \multirow{2}{*}{\multicolumn{2}{|c|}{ IZBOR KRITERIJEV }} & \multicolumn{2}{|c|}{ TRG. } & \multicolumn{2}{|c|}{ JAV. U. } & \multicolumn{2}{|c|}{ IND. } & \multicolumn{2}{|c|}{ FIN. S. } & \multicolumn{2}{|c|}{ F. OS. } \\
\hline & & F & $\mathrm{T}$ & $\mathrm{F}$ & $\mathrm{T}$ & F & $\mathrm{T}$ & F & $\mathrm{T}$ & F & $\mathrm{T}$ \\
\hline 3 & \multicolumn{11}{|l|}{ OCENJEVALNI KRITERIJI DRUŽBE } \\
\hline \multicolumn{12}{|c|}{ ORGANIZACIJSKA ZMOGLJIVOST } \\
\hline 1 & AVTORIZIRANO ZASTOPSTVO PROIZVAJALCA OPREME & & $\mathrm{x}$ & & $\mathrm{x}$ & & $\mathrm{x}$ & & $\mathrm{x}$ & & $\mathrm{x}$ \\
\hline 2 & DATUM IN ROK DOBAVE ALI DOKONČANJA DEL & & $\mathrm{x}$ & & $\mathrm{x}$ & & $\mathrm{x}$ & & $\mathrm{x}$ & & $\mathrm{x}$ \\
\hline 3 & DELEŽ NAROČIL, KI JIH BODO IZVEDLI PODIZVAJALCI & $\mathrm{x}$ & & $\mathrm{x}$ & $\mathrm{x}$ & $\mathrm{x}$ & $\mathrm{x}$ & $\mathrm{x}$ & $\mathrm{x}$ & & \\
\hline 4 & DOLOČITEV GARANCIJSKEGA ROKA ZA TEHNIČNO OPREMO & & $\mathrm{x}$ & & $\mathrm{x}$ & & $\mathrm{x}$ & & $\mathrm{x}$ & & $\mathrm{x}$ \\
\hline 5 & ELEKTRONSKA PRISTOPNA KONTROLA OBHODNEGA VAROVANJA IN INTERVENCIJE & $\mathrm{x}$ & & $\mathrm{x}$ & & $\mathrm{x}$ & & $\mathrm{x}$ & & $\mathrm{x}$ & \\
\hline 6 & ELEKTRONSKO SLEDENJE GOTOVINI & $\mathrm{x}$ & & $\mathrm{x}$ & & & & $\mathrm{x}$ & & & \\
\hline 7 & FUNKCIONALNE ZMOGLJVOSTI OPREME & & $\mathrm{x}$ & & $\mathrm{x}$ & & $\mathrm{x}$ & $\mathrm{x}$ & $\mathrm{x}$ & & $\mathrm{x}$ \\
\hline 8 & HITROST RAZPOLOŽLJIVOSTI SERVISNE SLUŽBE ZA ODPRAVO NAPAK & & $\mathrm{x}$ & & $\mathrm{x}$ & & $\mathrm{x}$ & & $\mathrm{x}$ & & $\mathrm{x}$ \\
\hline 9 & INFRASTRUKTURA PONUDNIKA & & & $\mathrm{x}$ & & $\mathrm{x}$ & & $\mathrm{x}$ & & $\mathrm{x}$ & \\
\hline 10 & IZVAJANJE INTERNIH STROKOVNIH IZPOPOLNJEVANJ & $\mathrm{x}$ & $\mathrm{x}$ & $\mathrm{x}$ & $\mathrm{x}$ & . & & $\mathrm{x}$ & $\mathrm{x}$ & & \\
\hline 11 & IZVAJANJE NOTRANJIH NADZOROV & $\mathrm{x}$ & $\mathrm{x}$ & $\mathrm{x}$ & $\mathrm{x}$ & $\mathrm{x}$ & $\mathrm{x}$ & $\mathrm{x}$ & $\mathrm{x}$ & $\mathrm{x}$ & $\mathrm{x}$ \\
\hline 12 & IZVAJANJE VADBENIH STRELJANJ & & & & & & & $\mathrm{x}$ & & & \\
\hline 13 & LASTNI RAZVOJ & & $\mathrm{x}$ & & $\mathrm{x}$ & & $\mathrm{x}$ & $\mathrm{x}$ & $\mathrm{x}$ & & $\mathrm{x}$ \\
\hline 14 & MEDSEBOJNA PODPORA POSAMEZNIH DEJAVNOSTI & $\mathrm{x}$ & $\mathrm{x}$ & $\mathrm{x}$ & $\mathrm{x}$ & $\mathrm{x}$ & $\mathrm{x}$ & $\mathrm{x}$ & $\mathrm{x}$ & & \\
\hline 15 & NAČRTOVANJE VAROVANJA IN VODENJE & $\mathrm{x}$ & & $\mathrm{x}$ & & $\mathrm{x}$ & & $\mathrm{x}$ & & & \\
\hline 16 & OBVLADOVANJE IZREDNIH DOGODKOV & $\mathrm{x}$ & $\mathrm{x}$ & $\mathrm{x}$ & $\mathrm{x}$ & $\mathrm{x}$ & $\mathrm{x}$ & $\mathrm{x}$ & $\mathrm{x}$ & $\mathrm{x}$ & $\mathrm{x}$ \\
\hline 17 & POGOII DELA & $\mathrm{x}$ & & $\mathrm{x}$ & & $\mathrm{x}$ & & $\mathrm{x}$ & & & \\
\hline 18 & POGOJI TEHNIČNEGA VZDRŽEVANJA & & $\mathrm{x}$ & & $\mathrm{x}$ & & $\mathrm{x}$ & & $\mathrm{x}$ & & $\mathrm{x}$ \\
\hline 19 & POOBLASTILO ZA VZDRŽEVANJE OPREME TEHNIČNEGA VAROVANJA & & $\mathrm{x}$ & & $\mathrm{x}$ & & $\mathrm{x}$ & & $\mathrm{x}$ & & $\mathrm{x}$ \\
\hline 20 & POPRODAJNE AKTIVNOSTI IN TEHNIČNA POMOČ & & $\mathrm{x}$ & & $\mathrm{x}$ & & $\mathrm{x}$ & & $\mathrm{x}$ & $\mathrm{x}$ & $\mathrm{x}$ \\
\hline 21 & RAZPOLOŽLJIVOST ČLOVEŠKIH IN MATERIALNIH VIROV ZA IZVAJANJE NALOG & $\mathrm{x}$ & & $\mathrm{x}$ & & $\mathrm{x}$ & $\mathrm{x}$ & $\mathrm{x}$ & $\mathrm{x}$ & & \\
\hline 22 & SLUŽBA ZA IZDELAVO OCEN TVEGANJ IN NAČRTOV VAROVANJ & $\mathrm{x}$ & & $\mathrm{x}$ & & $\mathrm{x}$ & & $\mathrm{x}$ & & & \\
\hline 23 & SPOSOBNOST IZVAJANJA NALOG & $\mathrm{x}$ & $\mathrm{x}$ & $\mathrm{x}$ & $\mathrm{x}$ & $\mathrm{x}$ & $\mathrm{x}$ & $\mathrm{x}$ & $\mathrm{x}$ & $\mathrm{x}$ & $\mathrm{x}$ \\
\hline 24 & ŠTEVILO IZVAJALCEV & $\mathrm{x}$ & & $\mathrm{x}$ & & $\mathrm{x}$ & & $\mathrm{x}$ & & & \\
\hline 25 & ŠTEVILO PRIREJENIH VOZIL ZA PREVOZ GOTOVINE & $\mathrm{x}$ & & $\mathrm{x}$ & & $\mathrm{x}$ & & $\mathrm{x}$ & & & \\
\hline 26 & URNIKI DELA & $\mathrm{x}$ & & $\mathrm{x}$ & & $\mathrm{x}$ & & $\mathrm{x}$ & & & \\
\hline 27 & ZMOGLJIVOST OPRAVLJANJA VEČ VRST DEJAVNOSTI NA RAZLIČNEM OBMOČJU & $\mathrm{x}$ & & $\mathrm{x}$ & & $\mathrm{x}$ & $\mathrm{x}$ & $\mathrm{x}$ & $\mathrm{x}$ & & \\
\hline 28 & ZMOŽNOST HKRATNIH VEČ MONTAŽ SISTEMOV TEHNIČNEGA VAROVANJA & & $\mathrm{x}$ & & $\mathrm{x}$ & & & & $\mathrm{x}$ & & \\
\hline 29 & ZMOŽNOST IZPOLNITVE POGODBE & $\mathrm{x}$ & $\mathrm{x}$ & $\mathrm{x}$ & $\mathrm{x}$ & $\mathrm{x}$ & $\mathrm{x}$ & $\mathrm{x}$ & $\mathrm{x}$ & $\mathrm{x}$ & $\mathrm{x}$ \\
\hline
\end{tabular}

Tabela 7: Pregled kriterijev, ki se nanašajo na kadrovsko zmogljivost in operativno ter tehnično zmogljivost 
V tabelah 4 do 7 smo predstavili štiri osnovne sklope kriterijev, ki so potrebni za učinkovito naročanje zasebnovarnostnih storitev.

V 1. sklopu so v Tabeli 4 zapisane licence, ki jih lahko pridobi zasebnovarnostno podjetje. V tem primeru je odločitev o ključnem kriteriju odvisna od oblike varovanja, ki jo potrebuje naročnik, ponudnik pa mora razpolagati $z$ ustrezno licenco.

$\mathrm{V}$ 2. sklopu so v Tabeli 5 obravnavani kriteriji veščin in znanj v sklopu kompetenc varnostnega osebja, ki izvaja naloge zasebnega varovanja. Izborni kriterij je ponovno vezan na obliko varovanja, ki jo naročnik potrebuje oziroma naroča, a z dodatnim razmislekom o stopnji zahtevnosti varovanja. Tu je potrebno razmisliti, kaj vse bo naročnik ob varovanju od posameznega izvajalca potreboval, na primer ali bo zahteval poleg fizičnega varovanja tudi izvajanje požarnega varovanja, ali poleg prevozov gotovine tudi intervencijska posredovanja in podobno.

Tretji sklop vsebuje pregled kriterijev, ki se nanašajo na organizacijsko, finančno in kadrovsko zmogljivost, kot prikazuje Tabela 6. Odločitev, kaj natančno potrebuje, je popolnoma prepuščena naročnikovi izbiri, vsekakor pa naročniku svetujemo, da dobro razmisli o kompetencah posameznikov, ki delujejo na njegovem varovanem območju in v njegovem imenu, ter izbere kriterije, ki odražajo potrebe, zahtevnost ter želje naročnika na način, da ustrezajo dejanskemu stanju na varovanem območju.

Četrti sklop (Tabela 7) vsebuje kriterije, ki jih družba ocenjuje kot pomembne pri zagotavljanju storitev zasebnega varovanja, in sicer: reference ponudnika, sistem vodenja kakovosti, plačevanje davkov in prispevkov, bančne garancije, zmožnost izvedbe naročenih storitev, ostali kriteriji, ki so vezani na posamezne zahteve naročnika. Tudi v sklopu 4 ne gre prezreti, da se mora naročnik odločiti, kaj želi in potrebuje in na podlagi tega pripraviti zahteve in razpisno dokumentacijo.

Ob upoštevanju vseh štirih sklopov lahko naročnik pri pripravi naročila dejansko izbere tiste kriterije, ki najbolj odražajo njegove potrebe in zahteve. Dodana vrednost ob upoštevanju pripravljenih kriterijev se kaže predvsem v nadgradnji standardnih kriterijev, kot so licence, cena, bančna garancija. Ob izboru dodatnih kriterijev tako dobi storitve, ki kar najbolj zadovoljujejo njegove potrebe. 


\section{Zaključek}

Spreminjajoče se varnostno okolje prinaša nove in kompleksne oblike ogrožanja varnosti, ki jih prebivalci, vključno z uporabniki zasebnovarnostnih storitev, pogosto ne zaznajo niti kot izzive, kaj šele kot resne varnostne probleme. Vsem, ki delujejo na področju zagotavljanja varnosti, mora biti v interesu, da prebivalci ne občutijo posledic varnostnih groženj, da lahko delajo in živijo v varni in uspešni družbi, kjer je varnost dobrina, ki je cenjena. Pomemben pogoj za to pa je, da so tisti, ki varovanje naročajo, primerno opremljeni z orodji, da to lahko učinkovito počno. Eno izmed orodij je tudi model naročanja zasebnovarnostnih storitev, ki smo ga razvili in ga predstavljamo v tem priročniku.

V Sloveniji sta področji zasebnega varovanja in javnega naročanja na splošno dobro zakonsko urejeni. Kljub temu opažamo, da še tako dobri predpisi in smernice naročnikom zasebnovarnostnih storitev povzročajo določene težave. Naročniki se soočajo predvsem s časovno stisko, pomanjkanjem znanja in s (pre)veliko količino informacij. Informacije lahko naročniki najdejo v različnih zakonih, kot sta Zakon o zasebnem varovanju in Zakon o javnem naročanju, ter na spletni strani Zbornice za razvoj slovenskega zasebnega varovanja. Prav tako lahko informacije pridobijo pri posameznih ponudnikih storitev. Namen priročnika je naročnikom prihraniti čas in zmanjšati število napak pri naročanju storitev. In vse to na preprost in razumljiv način. Predstavljene tabele lahko naročniki uporabijo tudi kot kontrolnik zahtev in želenih storitev, nenazadnje tudi ustrezne kakovosti ponudnika in njegovih storitev. Z uporabo kriterijev, predstavljenih v priročniku, je možno že na začetku oceniti, ali zasebnovarnostno podjetje, ki se je odzvalo na razpis javnega naročila oziroma na povpraševanje, sploh ustreza minimalnim zakonskim in kvalitativnim kriterijem za izvedbo storitev.

Ugotovili smo namreč, da naročniki zasebnovarnostnih storitev običajno ne poznajo dovolj dobro področja zasebnega varovanja in na podlagi tega ne vedo, kaj točno potrebujejo. Zato dostikrat niso zadovoljni s ponudniki oziroma ponudbami, ki jih izberejo. Do sedaj še ni bilo konkretno določenih kriterijev, po katerih bi naročnik natančno vedel, na kaj mora biti pozoren pri naročanju zasebnovarnostnih storitev. Zato se ti po navadi odločajo zgolj na podlagi cene. Soočamo se torej s problemom razmerja med 
kakovostjo in ceno, prav tako pa zasebnovarnostna podjetja nimajo konkretno opredeljenih okvirov glede cene svojih storitev.

$\mathrm{V}$ priročniku predstavljen model služi naročnikom varnostnih storitev za pripravo razpisov in razpisnih pogojev ter omogoča prepoznavanje in analizo kompetenc posameznih izvajalcev zasebnega varovanja na podlagi merljivega točkovanja. Hkrati pa naročniku omogoča pregleden nadzor nad izbranim izvajalcem zasebnega varovanja.

Namen publikacije je tako na eni strani izobraževanje in ozaveščanje naročnikov zasebnovarnostnih storitev, po drugi strani pa tudi izvajalcev, saj lahko ti ugotovitve in model iz priročnika uporabijo kot svojo strateško poslovno prednost.

$\mathrm{V}$ priročniku so poleg zakonskih zahtev predstavljeni kriteriji za izbor izvajalcev zasebnovarnostnih storitev po naslednjih sektorjih: trgovini, javni upravi, industriji, fizičnih osebah/hišah in finančnem sektorju. Označena polja v tabelah predstavljajo obvezne kriterije za zagotavljanje zakonitega izvajanja dejavnosti varovanja, o ostalih kriterijih pa se naročnik odloča $\mathrm{v}$ skladu $\mathrm{z}$ oceno tveganja in posvetovanja s strokovnjaki znotraj ter zunaj organizacije, na podlagi tako pridobljenih ponudb pa zvišuje kakovost zasebnovarnostnih storitev, ki mu jih zagotavlja izbrana zasebnovarnostna družba. Ob tem ne gre pozabiti, da lahko naročnik ravno z dodatnimi kriteriji, ki presegajo zakonske zahteve in najnižjo ceno zasebnovarnostnih storitev, izvaja učinkovit nadzor nad ponudniki zasebnovarnostnih storitev, saj je že v ponudbi in kasneje $\mathrm{v}$ pogodbenem razmerju jasno opredelil zahteve in kriterije, ki morajo biti stalno izpolnjeni.

$\mathrm{Na}$ ta način je dosežen še en namen priročnika, in sicer razširiti ugotovitve, predloge in znanje o naročanju zasebnovarnostnih storitev v Republiki Sloveniji s poudarkom na določanju več kriterijev, in ne zgolj najnižje cene, kajti učinkovito naročanje storitev zasebnega varovanja s pregledom potreb ter zahtev pripelje do zadovoljstva tako naročnika kot tudi ponudnika. Prav s strnjenim pregledom področja zasebnega varovanja in javnega naročanja, predvsem pa z usmeritvami, ki so na voljo v priloženih tabelah, bo omogočeno enostavnejše upravljanje $\mathrm{z}$ naročanjem zasebnega varovanja, saj so naročnikom in ponudnikom vse ključne informacije o naročanju storitev ter seznam vse ustrezne zakonodaje s tega področja podane na enem mestu. 


\section{Viri in literatura}

Antić, E. (2017). Opet presudan kriterij najniže cijene! Zaštita. Pridobljeno na http://zastita.info/hr/clanak/2017/2/opet-presudan-kriterij-najnize-cijene!,1595,20294.html

Aproser. (2016). Act 5/2014 on Private Security (Unofficial translation). Pridobljeno na http://aproser.es/web/ wp-content/uploads/2016/o6/Act-5-2014-on-Private-Security.-Unofficial-translation.pdf

Ballesteros R., R. (10. 06. 2016). Interior instalara cuarteles de la Guardia Civil en las centrales nucleares. Pridobljeno na https://www.elconfidencial.com/espana/2016-o6-10/interior-instalara-cuarteles-de-la-guardia-civil-en-las-centrales-nucleares_1213960/?fbclid=IwAR3_QnkVgpdac7tJA8iqkj5djBdcmYN44C5uwySsu88Z4OxQ26AoLeDj-3e4

Bucchi, F. in Casini, S. (5. 2016). Italy. V J. Davey in A. Gatenby (ur.), The Government procurement Review, 4th edition. London: Law Business Research Ltd. Pridobljeno na https://thelawreviews.co.uk//digital_assets/bc3bb225-3cf4-4c75-b481-e376fd8odd21/The-Government-Procurement-Review-4th-ed.pdf

Button, M. (2007). Assessing the Regulation of Private Security across Europe. European Journal of Criminology, 4(1), 109-128. Pridobljeno na https://journals-sagepub-com.ezproxy.lib.ukm.si/doi/ pdf/10.1177/1477370807071733

CEAs. (2015). U korak sa privatnim sektorom bezbednosti-II. Pridobljeno na https://www.ceas-serbia.org/ images/2015-i pre/U_korak_sa_privatnim_sektorom_bezbednosti_II.pdf

Coess. (2004). Panoramic Overview of Private Security Industry in the 25 Member States of the European Union. Pridobljeno na http://psm.du.edu/media/documents/reports_and_stats/global_data_and_statistics/coess_facts-figures_2004.pdf

Coess. (2011). Coess Fact and Figures 2011. Pridobljeno na https://www.coess.org/newsroom. php?page $=$ facts-and-figures

Coess. (2013). Coess Fact and Figures 2013. Pridobljeno na https://www.coess.org/newsroom. php? page $=$ facts-and-figures

Coess. (2013). Private security services in Europe. Pridobljeno na file:///C:/Users/Mitja\%20 Pre\%C5\%A1lji\%C4\%87/Downloads/ff-2013-private-security-services-in-europe-coess-facts-and-figures\%2o(3).pdf

Coess. (n. d.). Nakup storitev zasebnega varovanja. Pridobljeno na http://www.mnz.gov.si/fileadmin/mnz.gov. si/pageuploads/Dpdvn/Zasebno_varovanje/Novi_Zzasv/SL_Best_Value_Manual_v15_Final.pdf

CoEss in Uni-Europa. (2014). Kupuvane na kačestveni častni uslugi za sigurnost. Pridobljeno na http://www. securebestvalue.org/wp-content/uploads/2014/11/Best_Value_Manual_BG.pdf

Direktiva o usklajevanju postopkov za oddajo nekaterih javnih naročil gradenj in storitev, ki jih oddajo naročniki na področju obrambe in varnosti. (2009). Direktiva 2009/81. Pridobljeno na https://eur-lex.europa. eu/legal-content/EL/Txt/?qid=1415011920358\&uri=CELEX:32009Loo81

Ec.europa.eu. (n. d.). Public procurement - Study on administrative capacity in the EU: Poland Country Profile. Pridobljeno na https://ec.europa.eu/regional_policy/sources/policy/how/improving-investment/ public-procurement/study/country_profile/pl.pdf

Elektro Gorenjska, d. d. (2017). Izvajanje storitev varovanja naročilo male vrednosti. Kranj: Dokumentacija v zvezi z oddajo javnega naročila. Pridobljeno na https://www.elektro-gorenjska.si/resources/files/pdf/ NMv17-012_Izvajanje_storitev_varovanja_-_objava.pdf

European Public Accountability Mechanism. (2019). Lithuania Public Procurement. Pridobljeno na http://europam.eu/?module=country-profile\&country=Lithuania\#info_PP

Gatenby, A., Gilliam, B. in Dobson, L. (5. 2016). United Kingdom. V J. Davey in A. Gatenby (ur.), The 
Government procurement Review, 4th edition. London: Law Business Research Ltd. Pridobljeno na https://thelawreviews.co.uk//digital_assets/bc3bb225-3cf4-4C75-b481-e376fd8odd21/The-GovernmentProcurement-Review-4th-ed.pdf

Generally about Law. (2007). Police.gov.cy. Pridobljeno na http://www.police.gov.cy/police/police.nsf/All/ $\mathrm{F}_{225103 \mathrm{C}_{3} \mathrm{~B}_{521} \mathrm{~F}_{1} \mathrm{CC} 2257 \mathrm{~A} 6900244 \mathrm{~F}_{19} \text { ?OpenDocument }}$

G.I.B. Info. (n. d.). Nova zakonodaja o javnih naročilih. Pridobljeno na https://www.gibinfo.de/ gibinfo/2010/3_10/neues-vergaberecht-in-deutschland

Izbira ponudbe najboljše vrednosti - priročnik za organizacije pri oddaji naročil za storitve zasebnega varovanja. (2000).

Kemijski inštitut. (2014). Izvajanje storitev varovanja prostorov (receptorsko-varnostna služba in fizično tehnično protipožarno varovanje). Ljubljana: Razpisna dokumentacija za javno naročilo. Pridobljeno na https://www.ki.si/fileadmin/user_upload/datoteke-splosno/Razpisi/2014/RD_varovanje.docx

Közbeszerzési Hatóság. (2019). Közbeszerzési Adatbázis. Pridobljeno na https://kba.kozbeszerzes.hu/ apex/f?p=103:35:1914899546226573

Kodeks javnih naročil. (2019). Pridobljeno na http://www.marche-public.fr/ccp/ccp-plan-legislative.htm

Kodeks o javnih naročilih. (2008). Kodeks 20/2008. Pridobljeno na https://dre.pt/web/guest/ legislacao-consolidada/-/lc/115287282/201902261429/73533921/diploma/indice

Komunala Kranj. (2016). Izvajanje zasebnega varovanja po postopku oddaje naročila male vrednosti. Kranj: Dokumentacija v zvezi z oddajo javnega naročila. Pridobljeno na http://www.komunala-kranj.si/sites/ default/files/public/javni\%2orazpisi/Dokumentacija_8-NMv-16_izvajanje\%2ozasebnega\%2ovarovanja. popravek_4.7..docx

Kunovski, B. (28. 11. 2017). Varnostne agencije kot nadomestek za Ministrstvo za notranje zadeve pri skladiščenju državnih objektov. Pridobljeno na https://sitel.com.mk/ agenciite-za-obezbeduvanje-kako-supstitut-na-mvr-vo-chuvanje-na-vitalni-drzhavni-objekti

Kuusniemi-Laine, A., Lähde, J., Nordenstreng-Sarkamo, L. in Kaariste, M. (5. 2016). Finland. V J. Davey in A. Gatenby (ur.), The Government procurement Review, 4th edition. London: Law Business Research Ltd. Pridobljeno na https://thelawreviews.co.uk//digital_assets/bc3bb225-3cf4-4C75-b481-e376fd8odd21/TheGovernment-Procurement-Review-4th-ed.pdf

Lastno pravo za varnostno industrijo. (2018). Git sicherheit 5/2018. Pridobljeno na https://www.securitas.de/ globalassets/germany/files/fachbeitrage/2018/2018-05_git-sicherheit-gesetz.pdf

Law on Agencies for protection of persons and property (2002). Offical Gazette of the Federation of Bosnia and Herzegovina. Pridobljeno na http://www.privatesecurityregulation.net/files/ FederationPrivateSecurityCompaniesLaw.pdf

Law on public procurement for Bosnia and Herzegovina. (2004). Parliamentary Assembly of BiH. (101/04). Pridobljeno na https://advokat-prnjavorac.com/legislation/Law-on-Public-Procurement-for-Bosniaand-Herzegovina.pdf

Likumi Lv. (2006). Apsardzes darbības likums. Pridobljeno na https://likumi.lv/doc.php?id=136109

Likumi Lv. (2017). Publisko iepirkumu likums. Pridobljeno na https://likumi.lv/doc.php?id=28776o

Marboe, P. J. (5. 2016). Austria. V J. Davey in A. Gatenby (ur.), The Government procurement Review, 4th edition. London: Law Business Research Ltd. Pridobljeno na https://thelawreviews.co.uk//digital_assets/ bc3bb225-3cf4-4c75-b481-e376fd8odd21/The-Government-Procurement-Review-4th-ed.pdf 
Mestna občina Maribor. (2018). Varovanje premoženja Mestne občine Maribor za obdobje 4 let. Maribor: Dokumentacija v zvezi z oddajo javnega naročila.

MF Security solutions. (n. d.). Varnostne naloge. Pridobljeno na https://mfsecurity.dk/vagtopgaver/

Ministrstvo za gospodarski razvoj in tehnologijo. (2006). Oddaja javnega naročila blaga po odprtem postopku za opravljanje varnostno-receptorskih storitev in tehničnega varovanja. Ljubljana: Razpisna dokumentacija. Pridobljeno na http://www.mgrt.gov.si/fileadmin/mgrt.gov.si/pageuploads/gs_razpis_razpisna_dokumentacija_060714.pdf

Ministrstvo za javno upravo. (2019). Smernice za javno naročanje storitev zasebnega varovanja. Pridobljeno na http://www.djn.mju.gov.si/

Nacionalni računi in BDP. (Julij, 2018). Eurostat. Pridobljeno na https://ec.europa.eu/eurostat/statistics-explained/index.php?title=National_accounts_and_GDP/sl\#Razvoj_BDP_v_EU:_rast_od_leta.C2.Ao2013

Pravilnik o izvajanju Zakona o zasebnem varovanju. (2011). Uradni list RS, (100/11).

Private Security Law Slovakia (2005). On the provision of private security services and on amendments and supplements to certain laws (Private Security Act). Pridobljeno na http://www.privatesecurityregulation. net/files/2005\%20Law\%200n\%2oPrivate\%20Security\%20Services.pdf

Private Security (Licensing and Standards) Regulations (2005). Irish statute book.ie. S.I. No. 834/2005. Pridobljeno na http://www.irishstatutebook.ie/eli/2005/si/834/made/en/print

Pursiainen, C. (2018). Critical infrastructure resilience: A Nordic model in the making?. International Journal of Disaster Risk Reduction, 27, 632-641. Pridobljeno na https://reader.elsevier.com/reader/sd/ piiS2212420917301644?token=7ED4F174BA92E4960CCCBBBB7B6BEFFD1EF3E556B8oEE9BC985B91D51FE05A5238A7834C999CAE2EA04EB64629C47A47

Replica. (17. 12. 2011). Elektrarna Cernavoda porabi 1,6 milijonov levov. Pridobljeno na https://www.replicaonline.ro/paza-centralei-de-la-cernavoda-inghite-inca-1-6-milioane-de-lei-44870/

Republika Slovenija: Ministrstvo za notranje zadeve. (2019). Zasebno varovanje. http://www.mnz.gov.si/si/ mnz_za_vas/zasebno_varovanje_detektivi/zasebno_varovanje/

Riigi Teataja. (2010). Turvaseadus. Pridobljeno na https://www.riigiteataja.ee/akt/106122010010

Riigi Teataja. (2019). Riigihangete seadus. Pridobljeno na https://www.riigiteataja.ee/ akt/101072017001?leiaKehtiv

Rovira, M. (18. 11. 2015). Las centrales nucleares encomiendan su seguridad a la Guardia Civil. Pridobljeno na https://elpais.com/ccaa/2015/11/18/catalunya/1447842833_712087.

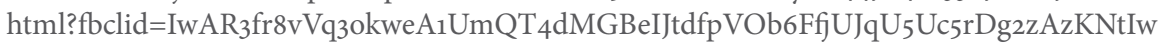

Security Industry Authority [SIA]. (n. d.a). Before You Apply. https://www.sia.homeoffice.gov.uk/Pages/licensing-before.aspx

SLOV-LEx právny informačný portál. (2019). ZÁkon o verejnom obstarávaní a o zmene a doplnení niektorých zákonov. Pridobljeno na https://www.slov-lex.sk/pravne-predpisy/SK/ZZ/2015/343/20190101

Sociétés de surveillance et de gardiennage. (2014). Mj.public.lu. Pridobljeno na http://mj.public.lu/functions/ faq/surveillance/index.html\#question 4

Sotlar, A. in Dvojmoč, M. (2018). Profesionalizacija zasebnega varstva v Sloveniji. Varstvoslovje, 20(3), 358-380.

Splošna uredba javnega naročila. (2003). Uredba, št. 49/2003. Pridobljeno na http:// www.madrid.org/wleg_pub/secure/normativas/contenidoNormativa.

jsf?opcion=VerHtml\&idnorma=2731\&word=S\&wordperfect=N\&pdf=S\#no-back-button 
Udbudsportalen. (n. d.). Direktive, zakoni in pravila. Pridobljeno na https://udbudsportalen.dk/ udbudsguiden/ret-regler/udbudsregler/

Van Steden, R. in Sarre, R. (2007). The Growth of Private Security: Trends in the European Union. Security Journal, 20, $(222$ - 235). Pridobljeno na https://link-springer-com.ezproxy.lib.ukm.si/article/10.1057\%2Fpalgrave.sj. 8350052

Verband der Sicherheitsunternehmen Österreichs. (n. d.). Fachgruppe sicherheitsdienstleister. Pridobljeno na https://vsoe.at/ueber-uns/fachgruppen-im-vsoe/sicherheitsdienstleister.html

VlaAnderen. (n. d.). Zakaj zakonodaja o javnih naročilih?. Pridobljeno na https://lokaalbestuur.vlaanderen. be/overheidsopdrachten/toelichting-regelgeving/situering-en-toepassingsgebied

Wolters Kluwer. (2005). törvény a személy- és vagyonvédelmi, valamint a magánnyomozói tevékenység szabályairól. Pridobleno na https://net.jogtar.hu/jogszabaly?docid=A0500133.TV

Zakon o javnem naročanju (ZJN-3). (2016). Uradni list RS, (91/5, 14/18).

Zakon o javnim nabavkama. (2015). Službeni glasnik RS, (124/12, 14/15, 68/15).

Zakon o javnim nabavkama. (2017). Službeni list Crne Gore, (042/11, 057/14, 028/15, 042/17).

Zakon o javnih naročilih. (o1. 12. 2016). Zakon o javnih naročilih 1145. Pridobljeno na https:// www.riksdagen.se/sv/dokument-lagar/dokument/svensk-forfattningssamling/ lag-20161145-om-offentlig-upphandling_sfs-2016-1145

Zakon o privatno obezbeđenju. (2013). Službeni glasnik RS, (104/13, 42/15).

Zakon o javnoj nabavi. (2016). Narodne novine, (120/16). Pridobljeno na http://www.propisi.hr/print. php?id=14495

Zakon o privatnoj zaštiti. (2003, 2010). Narodne novine, (68/o3, 31/10, 139/10). Pridobljeno na https://www. zakon.hr/z/291/Zakon-o-privatnoj-za\%C5\%A1titi

Zakon o sektorskih javnih naročilih. (2016). Zakon 22/2016. Pridobljeno na http://anap.gov.ro/web/wp-content/uploads/2016/05/Legea-nr-99per2016-actualizata-4-iunie-2018.pdf

Zakon o spremembah in dopolnitvah Zakona o zasebnem varovanju (Zzasv-в). (2009). Zbirke Državnega zbora RS - predlogi zakonov, (46/o9). Pridobljeno na http://www2.gov.si/zak/Pre_Zak.nsf/13245fa6aof65cogc1256616002a408e/ dc8odeae20023843c125757boo407296? OpenDocument\&ExpandSection=1

Zákon o zadávání veřejných zakázek. (29. 4. 2016). Zákony pro lidi CZ. 134/2016. Pridobljeno na https://www. zakonyprolidi.cz/cs/2016-134

Zakon o zasebnem varovanju (ZZasV-1). (2011). Uradni list RS, (17/11).

Zakon o zaštiti lica i imovine. (2013). Službeni list Crne Gore, (01-1954/2).

Zakon za privatno obezbeduvanje. (2013). Služben vesnik na Republika Makedonija, (164/13).

Zbornica za razvoj slovenskega zasebnega varovanja. (2012). Etični kodeks zasebnega varovanja. Pridobljeno na http://www.zrszv.si/media/Eticni_kodeks.pdf

Zemljič, A. (2010). Primerjalna analiza za zasebno varovanje - Študija primera Avstrijske Štajerske in slovenskega Podravja (Diplomsko delo). Ljubljana: Fakulteta za varnostne vede. Pridobljeno na https://dk.um. si/Dokument.php?id=21926

Zakon za obštestvenite porăčki. (2018). Pridobljeno na https://www.lex.bg/bg/laws/ldoc/2137180492

Zakon za častnata ohranitelna deynost. (2016). Pridobljeno na https://www.lex.bg/bg/laws/ldoc/2136735703 


\section{KAZALO TABEL}

Tabela 1: Zakonska ureditev zasebnega varovanja v 32 evropskih državah. . . . . . . . . 5

Tabela 2: Pregled urejenosti sistema javnega naročanja v 32 evropskih državah . . . . . 6

Tabela 3: Posebnosti predhodno predstavljenih javnih naročil . . . . . . . . . . . 33

Tabela 4: Pregled kriterijev, ki se nanašajo na licence in varnostno osebje, ki izvaja varovanje . . . . . . . . . . . . . . . . . . 37

Tabela 5: Pregled kriterijev, ki se nanašajo na veščine in znanja v sklopu kompetenc varnostnega osebja, ki izvaja varovanje . . . . . . . . . . . . 38

Tabela 6: Pregled kriterijev, ki se nanašajo na orga"nizacijsko, finančno in kadrovsko zmogljivost . . . . . . . . . . . . . . . . . . . . . . . . 39

Tabela 7: Pregled kriterijev, ki se nanašajo na kadrovsko zmogljivost in operativno ter tehnično zmogljivost $\ldots \ldots \ldots \ldots \ldots$. . . . . . . 41 


\section{SEZNAM AVTORJEV}

\section{SODELUJOČI MENTORJI}

Pedagoški mentorji:

Izr. prof. dr. Andrej Sotlar

Doc. dr. Beković Miloš

Doc. dr. Miha Dvojmoč

Delovna mentorja:

Mag. Gorazd Mandelj

Milan Vačovnik
Univerza v Mariboru, Fakulteta za varnostne vede univ. dipl. inž. el., Univerza v Mariboru, Fakulteta za elektrotehniko, računalništvo in informatiko Univerza v Mariboru, Fakulteta za varnostne vede

direktor podjetja GM PROJEKT, projektni management, elektrotehnični inženiring in poslovno svetovanje, d. o. o. svetovalec uprave za kakovost podjetja AKTIVA PRIVA, družba za storitve, trgovino in proizvodnjo, d. o. o.

\section{SODELUJOČI ŠTUDENTI}

Anja Babnik

Boštjan Ban

Eva Blatnik

Tina Dernovšek

Nika Gaberšek

Daniela Hozjan

Mitja Prešljić študentka varstvoslovja, Univerza v Mariboru, Fakulteta za varnostne vede študent varstvoslovja, Univerza v Mariboru, Fakulteta za varnostne vede študentka varstvoslovja, Univerza v Mariboru, Fakulteta za varnostne vede študentka oblikovanja vizualnih komunikacij, Univerza v Ljubljani, Akademija za likovno umetnost in oblikovanje študentka varstvoslovja, Univerza v Mariboru, Fakulteta za varnostne vede študentka varstvoslovja, Univerza v Mariboru, Fakulteta za varnostne vede študent varstvoslovja, Univerza v Mariboru, Fakulteta za varnostne vede 


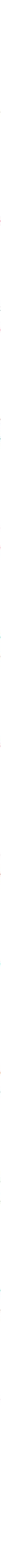

